\title{
Geological, geochemical and Rb-Sr isotopic studies on tungsten mineralised Sewariya-Govindgarh granites of Delhi Fold Belt, Rajasthan, NW India
}

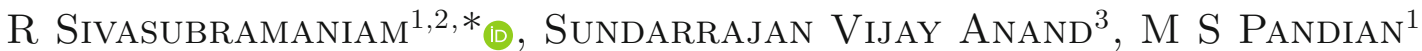 \\ and S BALAKRISHNAN ${ }^{1}$ \\ ${ }^{1}$ Department of Earth Sciences, Pondicherry University, Puducherry 605014 , India. \\ ${ }^{2}$ Atomic Minerals Directorate for Exploration and Research, Shillong 793 019, India. \\ ${ }^{3}$ Department of Earth Sciences, Eritrea Institute of Technology, Asmara 12676, Eritrea. \\ *Corresponding author. e-mail: sivasubramaniamr@gmail.com
}

MS received 28 September 2017; revised 26 March 2018; accepted 31 March 2018; published online 17 December 2018

Neoproterozoic granites are widespread in the Delhi Fold Belt of the Aravalli craton, some of which are associated with tungsten mineralisation. In one such instance, the volcano-sedimentary sequence of Barotiya Group in the South Delhi Fold Belt is intruded by a pluton of biotite granite gneiss known as Sewariya Granite (SG) and later by stocks and dyke swarm of tourmaline leucogranite known as Govindgarh Granite (GG). GG magmatism was associated with wolframite mineralisation in hydrothermal quartz veins occurring along the sheared contact between SG pluton and Barotiya mica schist. SG pluton shows the evidence of ductile and brittle deformations, whereas GG is by and large undeformed. Apart from quartz and feldspars, SG contains biotite and muscovite, and GG contains muscovite, tourmaline and garnet. Although both SG and GG are peraluminous, SG has a wide range of $\mathrm{SiO}_{2}$ and narrow range of alkalis, and GG has a narrow range of $\mathrm{SiO}_{2}$ and a wide range of alkalis. REE (rare Earth elements) modelling shows that the parent magma of SG and GG was derived from partial melting at different crustal levels. Rb-Sr isotope data of GG yield a mineral isochron age of $860 \pm 7.4 \mathrm{Ma}$ which represent the time of igneous crystallisation and cooling of the granite to less than $400^{\circ} \mathrm{C}$.

Keywords. Aravalli craton; Delhi Supergroup; S-type granite; tungsten mineralisation; geochemistry; geochronology.

\section{Introduction}

Granites form a major component of the continental crust and the granitic melts are important media for the transport of lithophile and few other elements from lower to the upper continental crust. Hydrothermal activity associated with granite magmatism has produced the majority of the known greisen type and skarn hosted $\mathrm{Sn}-\mathrm{W}$ deposits. During Neoproterozoic period, there was widespread acid magmatism in the Aravalli craton, particularly within and to the west of the Delhi Fold Belt, some of which are associated with wolframite mineralisation in Degana, Balda and Sewariya areas (Pandian 1999). In the present study area, metamorphosed volcanosedimentary formations of Barotiya Group (the western most basin of South Delhi Fold Belt (SDFB)) are flanked to the west by pre-Delhi marble and gneisses, and intruded by a large pluton 
of Sewariya Granite (SG), which is a foliated, porphyritic to equigranular biotite granite gneiss. Geological Survey of India (GSI) discovered wolframite mineralisation in quartz-tourmaline veins occurring near Kalni, Motiya, Pipaliya, Richmaliyan and Kotariya, localised along the sheared intrusive contact between SG and Barotiya mica schist (Jain and Bhattacharjee 1992; Bhattacharjee et al. 1993; Chattopadhyay et al. 1995). Banerji and Pandit (1995) reported the occurrence of a leucogranite in the form of small pods and irregular bodies within meta-argillites of Barotiya Group along with an $18 \mathrm{~km}$ long NNE-SSW trending belt to the east of these tungsten prospects. Pegmatites associated with these leucogranite bodies were reported to contain Li-mineralisation in the form of lithium phosphate minerals ferrisicklerite and triphyllite (Bhattacharjee et al. 1993). Pandian and Dutta (2000) recognised and mapped larger exposures of a tourmaline leucogranite along LuniSagarmati river section near Govindgarh, about $15 \mathrm{~km} \mathrm{NE}$ of Sewariya. In view of its distinct geological, petrographic and geochemical characteristics and relevance to tungsten mineralisation in Sewariya area, this granite body has been named as Govindgarh Granite (GG). Based on the geochemical characteristics of SG pluton and GG from Sagarmati River, Ray et al. (2015) have inferred a metasedimentary protolith for both these granites and that the anatectic conditions prevalent during their origin were disparate.

Geochronological data are available for several other granites of the Aravalli craton (Crawford and Compston 1970; GSI 1982; Choudhary et al. 1984; Tobisch et al. 1994; Srivastava and Sinha 1997; Torsvik et al. 2001; Pandit et al. 2003; Ashwal et al. 2013; Arif et al. 2017). In this paper, we present the petrographic, geochemical and $\mathrm{Rb}-$ $\mathrm{Sr}$ isotopic characteristics of the granites from Sewariya-Govindgarh areas in the background of their geological setting and relevance to tungsten mineralisation.

\section{Geology of the study area}

SG is one of the largest granite pluton occurring along the western margin of SDFB, exposed over a strike length of $35 \mathrm{~km}$ along NNE with an average width of about $6 \mathrm{~km}$ (Jain and Bhattacharjee 1992) (figure 1). SG is grey coloured, medium to very-coarse grained and generally shows a gneissic foliation trending $\mathrm{N} 20-30^{\circ} \mathrm{E}$ with steep to near-vertical dip. It contains quartz, microcline, plagioclase, biotite and muscovite as major phases and occasionally metasomatic tourmaline occurs as an accessory phase. SG is intruded by quartz veins, few 10s of centimetre thick and extending for few $\mathrm{m}$, consisting only of grey quartz. These quartz veins follow different strike directions (e.g., N50 $\mathrm{E}$ in Kalni; $\mathrm{N} 10^{\circ} \mathrm{E}$ in Kotariya) and often show evidence of brittle deformation along with the host SG.

The present study has revealed that GG is also a major litho unit occurring in the form of stocklike bodies and as dyke swarm intruding into the Barotiya rocks and SG in an NNE-SSW trending zone extending for about $20 \mathrm{~km}$ from Kalni in the north to Sewariya in the south, and about $8 \mathrm{~km}$ wide, limited to Govindgarh-Pisangan in the east and Sewariya-Kurki-Bijathal in the west. Two different varieties of GG are recognised: (i) an older medium-grained granite (MGG), which is either massive or layered with alternating tourmalinerich and tourmaline-poor bands and (ii) a younger coarse-grained granite (CGG), which appears to be the product of pegmatitic stage (figure $2 a$ and $b$ ). The two varieties of GG share a common mineral assemblage of quartz, sodic plagioclase, K-feldspar, tourmaline and muscovite with accessory garnet and apatite. Both types of GG are occasionally intruded by milky white quartz-tourmaline veins, many of which are observed along Sagarmati River near the Govindgarh village (figure 2a). There is a clear intrusive relationship between $\mathrm{SG}$ and $\mathrm{GG}$, with the dykes of GG cutting across SG pluton at many places near Richmaliyan, Kotariya, Bijathal and Pipaliya (figure 2c).

There are few discrete shear zones in SG pluton showing brittle and ductile deformation trending NNE-SSW in the western margin of the study area. Along with its contact with mica schist, there are several instances where SG shows mylonite fabric with grain size reduction and evidence of dynamic recrystallisation (e.g., development of quartz ribbons) in a few metre wide zone (figure 2d). Apart from these ductile shear zones (DSZ) localised along the intrusive margin of SG, there are few DSZ occurring well within SG. In addition to the ductile shearing localised generally along or near to the intrusive contact of SG with Barotiya rocks, effects of brittle deformation are also observed in SG in three locations: (i) in the northern part of the study area, large outcrops of coarse-grained SG occur near Kalni with widespread development of thin bands of cataclasite in various orientations (trending $\mathrm{N} 20^{\circ} \mathrm{W}, \mathrm{N} 50^{\circ} \mathrm{W}, \mathrm{N}-\mathrm{S}$ ). Among these 


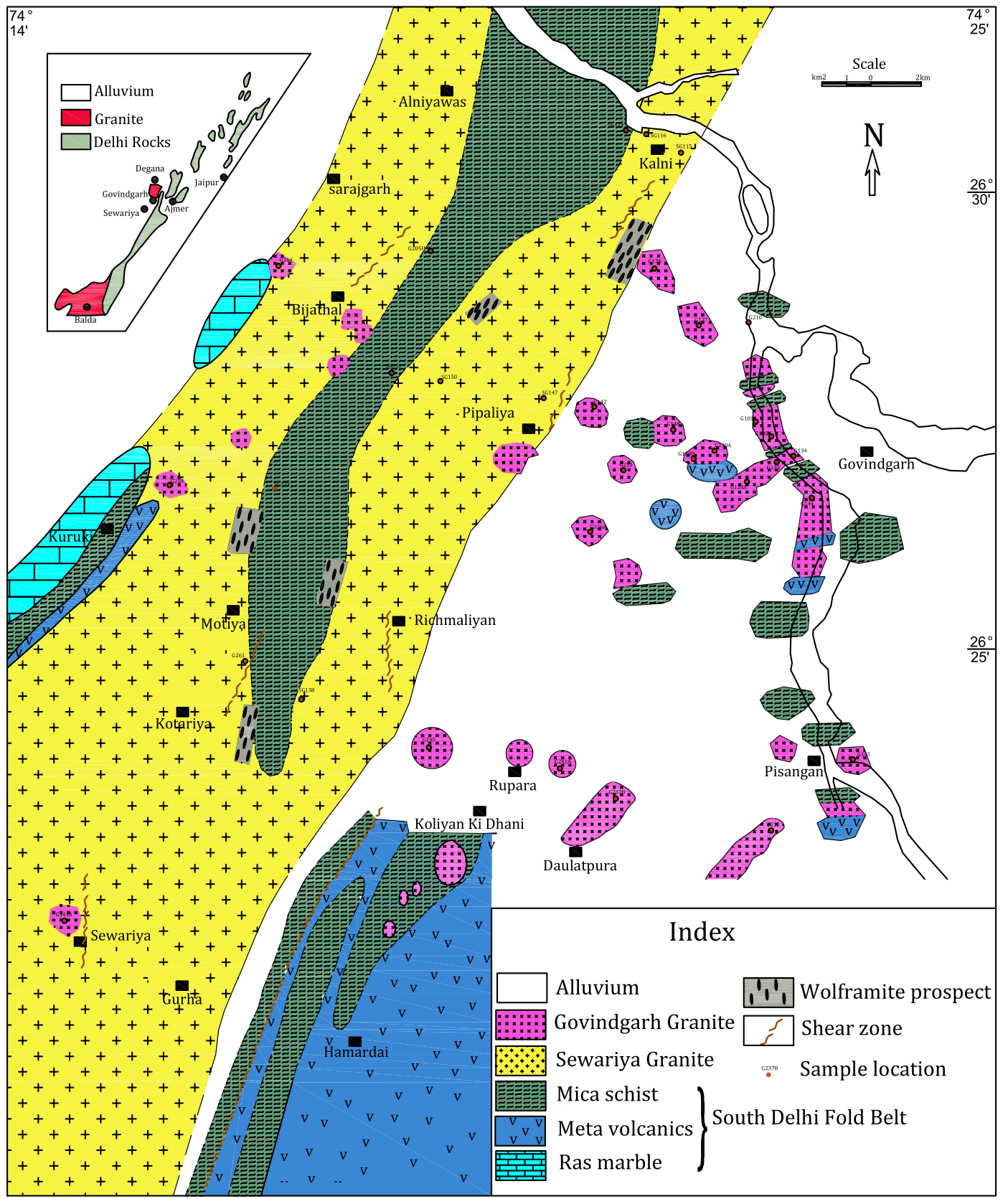

Figure 1. Geological map of Sewariya-Govindgarh area (after Bhattacharjee et al. 1993; Pandian and Dutta 2000). The inset shows tungsten deposits in Delhi Fold Belt.

cataclasite bands, early formed ones are displaced (up to few centimetres) by later ones indicating their progressive development during the brittle shearing event (figure 2e). Grey quartz veins occurring within SG are also displaced by these cataclasite bands by few centimetre to more than a metre; (ii) in a small ridge to the NE of Bijathal, ultramylonite band of SG is brecciated indicating a later brittle deformation within the DSZ; and (iii) veins of pseudotachylite, up to few centimetre thick and few metre long, traverse through mylonitised SG in Chhorola Bala river bank to the east of Kotariya village (figure 2f), where these pseudotachylite veins are parallel-sub-parallel to the mylonite foliation of SG which trends $\mathrm{N} 20^{\circ} \mathrm{E}$; this is another instance of later brittle deformation within the DSZ.

Near to the NNE-SSW trending shear zones, Barotiya rocks and at few places GG have developed asymmetric folds whose axes are generally NNE-SSW trending (figure $2 \mathrm{~g}$ ). Apart from a few such instances, GG does not show any evidence of deformation. At places, dykes of GG intrude into the folded Barotiya rocks parallel to axial plane 

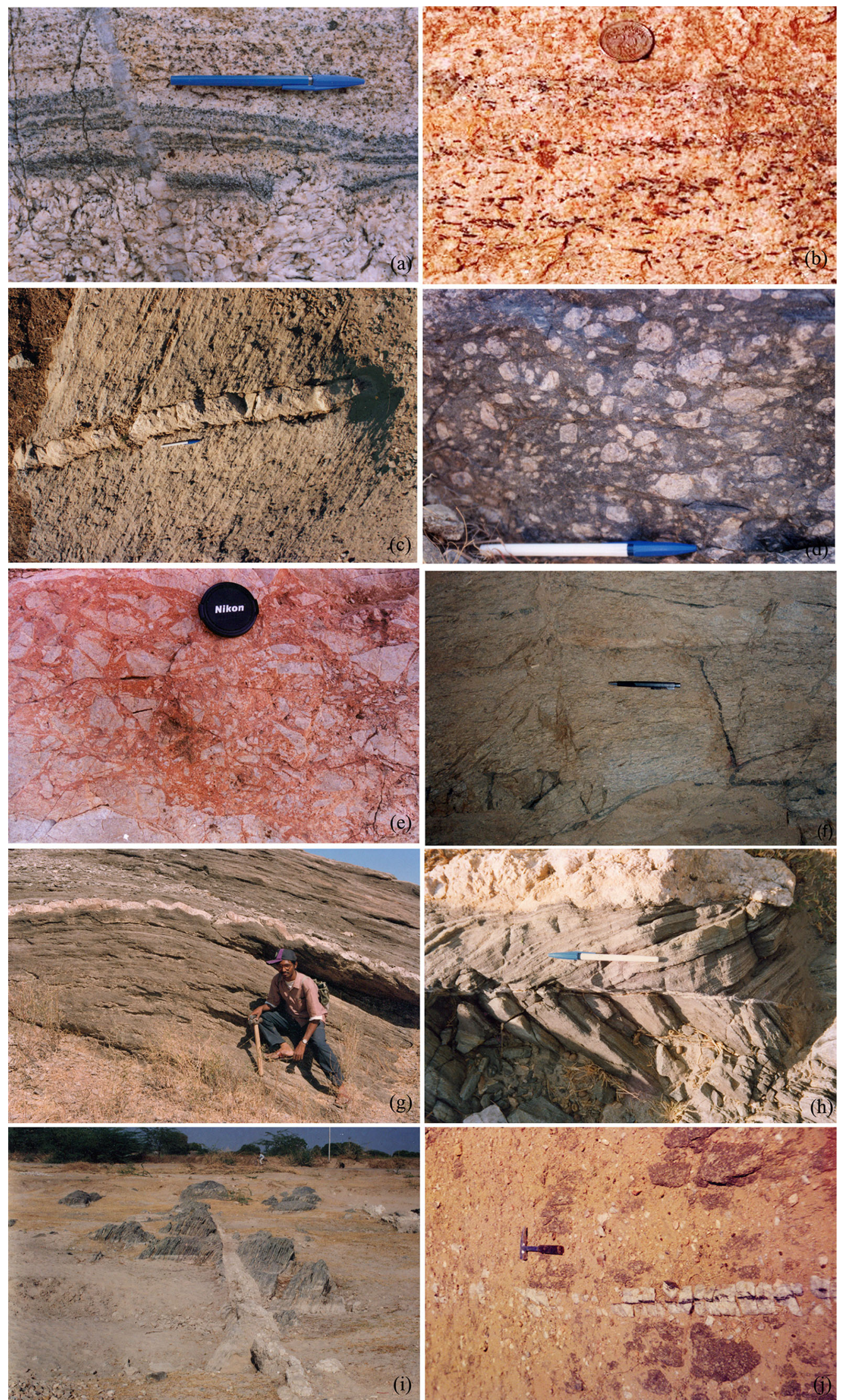
Table 1. A stratigraphical succession of Sewariya-Govindgarh area.

\begin{tabular}{|c|c|}
\hline \multirow{7}{*}{ Post-Delhi magmatism } & Milky white quartz veins with tungsten mineralisation \\
\hline & Coarse-grained Govindgarh Granite \\
\hline & Medium-grained Govindgarh Granite \\
\hline & .............Intrusive contact.................... \\
\hline & Ductile and brittle deformation of Barotiya rocks, SG and grey quartz veins \\
\hline & Grey quartz veins in Sewariya Granite \\
\hline & Sewariya Granite \\
\hline & ive contact............................................... \\
\hline \multirow[t]{2}{*}{ Delhi Supergroup } & Barotiya Group (mica schist, meta-volcanics) \\
\hline & uctural hiatus............................................ \\
\hline Pre-Delhi rocks & Ras marble, gneisses and amphibolite \\
\hline
\end{tabular}

of fold whose axis trends $\mathrm{N} 45^{\circ} \mathrm{E}$ (figure $2 \mathrm{~h}$ ) and also oblique to fold axis trending $\mathrm{N} 32^{\circ} \mathrm{E}$ (figure $2 \mathrm{i}$ ). Angular xenoliths of Barotiya rocks are common in GG and at few places, Barotiya rocks have undergone brittle deformation due to the intrusion of GG.

We have found that although wolframite-bearing quartz veins are hosted by mica schist of Barotiya Group and adjoining marginal portions of SG pluton, dykes or larger intrusive of GG are invariably present in close proximity to these mineralised zones. Moreover, there is a striking similarity in the mineral assemblage of medium-grained layered GG (representing magmatic phase), coarse-grained GG (representing pegmatitic phase), wolframitebearing quartz veins in the prospects and quartz veins occurring within GG (representing hydrothermal phase), characterised by the ubiquitous presence of tourmaline + muscovite \pm apatite. From these geological characteristics, it is inferred that the younger leucogranite magmatism produced successively the medium-grained GG (MGG), coarse-grained GG (CGG) and milky white quartz veins some of which contain wolframite (figure $2 \mathrm{j}$ ).

Figure 2. (a) Intrusive contact between medium-grained and coarse-grained GG. Younger quartz vein cuts through both (Sagarmati river); (b) magmatic layering in GG shown by tourmaline and garnet; (c) SG showing gneissic foliation, intruded by GG; (d) SG showing mylonite fabric (north of Sewariya); (e) brecciated ultramylonite in SG (NE of Bijathal); (f) veins of pseudotachylite in mylonitised SG (Chhorola Bala river east of Kotariya); (g) CGG folded along with Barotiya mica schist (near Govindgarh); (h) thin dyke of MGG occupying axial plane fracture in folded metabasic rock of Barotiya Group (Sagarmati river); (i) dyke of CGG cuts oblique to axial plane of folded meta-basic rock of Barotiya Group (Sagarmati river); (j) tungsten mineralised quartz-tourmaline vein in mica schist (Motiya prospect).
From the field relations, it is demonstrated that SG (biotite-bearing granitic gneiss) and GG (tourmaline-bearing leucogranite) were formed during two successive magmatic events, of which GG is a younger phase. The presence of NNESSW trending ductile and brittle shear zones in SG along the western margin of the study area indicate the upliftment of SG pluton from middle to upper crustal level. The succession of major geological events recorded in the study area is given in table 1 .

\section{Analytical methods}

Petrographic study supplemented by X-ray diffraction (XRD) analysis was carried out on the granites. Major and trace element analysis of granites was carried out using X-ray fluorescence spectrometer and atomic absorption spectroscopy (for Li) at Wadia Institute of Himalayan Geology, Dehradun, electron probe micro analysis (EPMA) of selected mineral grains was done at Institute Instrumentation Centre, IIT-Roorkee. Selected granite and mica schist samples were analysed for REE and W using ICP-AES, respectively, at School of Environmental Sciences, Jawaharlal Nehru University, New Delhi and Department of Earth Sciences, Pondicherry University. The chemical composition of tourmaline and garnet analysed by EPMA is given in tables 2 and 3. Major, trace element and REE data of rocks are given in tables 4 and 5. For geochronology, whole rock samples of SG and GG, and pure mineral fractions of plagioclase, garnet and muscovite from GG were analysed. Pure mineral fractions were obtained from powdered rock samples by using bromoform, isodynamic separator and by hand picking under a binocular microscope. Precisely, weighed samples were taken in a $3 \mathrm{ml}$ Savilax ${ }^{\circledR}$ 
Table 2. The chemical composition of tourmaline from different rock types in Sewariya-Govindgarh area.

\begin{tabular}{|c|c|c|c|c|c|c|c|c|c|c|}
\hline \multirow{2}{*}{$\begin{array}{l}\text { Wt\% } \\
\text { Points }\end{array}$} & \multicolumn{2}{|c|}{ Layered MGG } & \multicolumn{2}{|c|}{ MGG } & \multicolumn{2}{|c|}{ CGG } & \multicolumn{2}{|c|}{ Quartz vein } & \multicolumn{2}{|c|}{$\mathrm{SG}$} \\
\hline & Rim & Core & Rim & Core & Rim & Core & Rim & Core & Rim & Core \\
\hline $\mathrm{SiO}_{2}$ & 35.12 & 36.55 & 36.98 & 37.74 & 33.56 & 36.33 & 36.08 & 36.25 & 33.85 & 34.28 \\
\hline $\mathrm{TiO}_{2}$ & 0.19 & 0.28 & 0.37 & 0.55 & 0.13 & 0.21 & 0.65 & 0.47 & 0.42 & 0.34 \\
\hline $\mathrm{Al}_{2} \mathrm{O}_{3}$ & 31.27 & 31.00 & 32.09 & 33.21 & 28.79 & 30.71 & 29.94 & 29.46 & 31.8 & 31.71 \\
\hline $\mathrm{FeO}$ & 11.23 & 11.01 & 11.28 & 8.62 & 10.47 & 14.61 & 9.71 & 8.97 & 14.47 & 14.56 \\
\hline $\mathrm{MgO}$ & 2.32 & 2.25 & 3.10 & 4.91 & 0.84 & 0.68 & 4.04 & 4.42 & 0.67 & 0.87 \\
\hline $\mathrm{MnO}$ & 0.02 & 0.18 & 0.11 & 0.04 & 0.14 & 0.10 & 0.02 & 0.06 & 0.20 & 0.16 \\
\hline $\mathrm{CaO}$ & 0.14 & 0.15 & 0.20 & 0.34 & 0.09 & 0.08 & 0.01 & 0.04 & 0.27 & 0.25 \\
\hline $\mathrm{Na}_{2} \mathrm{O}$ & 1.91 & 1.72 & 1.93 & 1.87 & 1.69 & 1.54 & 2.13 & 2.01 & 2.02 & 1.94 \\
\hline \multicolumn{11}{|c|}{ Structural formula on the basis of 24.5 oxygen } \\
\hline $\mathrm{Si}_{\text {(Total) }}$ & 6.12 & 6.27 & 6.14 & 6.09 & 6.32 & 6.26 & 6.21 & 6.28 & 5.92 & 5.96 \\
\hline $\mathrm{Al}_{(\text {Total })}$ & 6.42 & 6.27 & 6.28 & 6.31 & 6.39 & 6.23 & 6.07 & 6.01 & 6.55 & 6.49 \\
\hline $\mathrm{Al}_{(\mathrm{Z})}$ & 5.85 & 5.69 & 5.79 & 5.81 & 5.65 & 5.69 & 5.69 & 5.64 & 6.00 & 5.99 \\
\hline $\mathrm{Ti}$ & 0.02 & 0.03 & 0.05 & 0.07 & 0.02 & 0.03 & 0.08 & 0.06 & 0.06 & 0.04 \\
\hline $\mathrm{Si}_{(\mathrm{Z})}$ & 0.12 & 0.27 & 0.14 & 0.09 & 0.32 & 0.26 & 0.21 & 0.28 & - & - \\
\hline $\mathrm{Al}$ & 0.57 & 0.58 & 0.49 & 0.5 & 0.74 & 0.54 & 0.38 & 0.37 & 0.55 & 0.50 \\
\hline $\mathrm{Fe}$ & 1.63 & 1.58 & 1.56 & 1.16 & 1.65 & 2.10 & 1.39 & 1.29 & 2.12 & 2.12 \\
\hline $\mathrm{Mg}$ & 0.60 & 0.58 & 0.77 & 1.18 & 0.24 & 0.17 & 1.03 & 1.14 & 0.17 & 0.23 \\
\hline $\mathrm{Mn}$ & - & 0.03 & 0.02 & 0.01 & 0.02 & 0.02 & - & 0.01 & 0.03 & 0.02 \\
\hline $\operatorname{Li}_{(Y)}$ & 0.19 & 0.23 & 0.16 & 0.14 & 0.35 & 0.17 & 0.20 & 0.19 & 0.13 & 0.13 \\
\hline $\mathrm{Ca}$ & 0.03 & 0.03 & 0.03 & 0.06 & 0.02 & 0.01 & - & 0.01 & 0.05 & 0.05 \\
\hline $\mathrm{Na}$ & 0.65 & 0.57 & 0.62 & 0.58 & 0.61 & 0.51 & 0.71 & 0.67 & 0.69 & 0.65 \\
\hline $\mathrm{X}_{(\mathrm{vac})}$ & 0.32 & 0.40 & 0.35 & 0.36 & 0.37 & 0.48 & 0.29 & 0.32 & 0.26 & 0.30 \\
\hline
\end{tabular}

Table 3. The chemical composition of garnet from mediumgrained $G G$.

\begin{tabular}{|c|c|c|c|c|}
\hline $\mathrm{Wt} \%$ & 1 & 2 & 3 & 4 \\
\hline $\mathrm{SiO}_{2}$ & 36.34 & 34.99 & 37.16 & 38.39 \\
\hline $\mathrm{TiO}_{2}$ & - & 0.01 & 0.01 & 0.01 \\
\hline $\mathrm{Al}_{2} \mathrm{O}_{3}$ & 20.82 & 20.03 & 20.9 & 20.63 \\
\hline $\mathrm{FeO}$ & 31.73 & 32.66 & 33.66 & 33.68 \\
\hline $\mathrm{MgO}$ & 0.61 & 0.90 & 1.00 & 1.04 \\
\hline $\mathrm{MnO}$ & 9.68 & 7.81 & 7.77 & 8.06 \\
\hline $\mathrm{CaO}$ & 0.51 & 0.33 & 0.40 & 0.35 \\
\hline \multicolumn{5}{|c|}{ Based on 12 oxygen } \\
\hline $\mathrm{Si}$ & 2.99 & 2.98 & 3.01 & 3.07 \\
\hline $\mathrm{Ti}$ & - & - & - & - \\
\hline $\mathrm{Al}$ & 2.00 & 2.00 & 1.99 & 1.94 \\
\hline $\mathrm{Fe}$ & 2.19 & 2.32 & 2.28 & 2.25 \\
\hline $\mathrm{Mg}$ & 0.08 & 0.11 & 0.12 & 0.12 \\
\hline Mn & 0.68 & 0.56 & 0.53 & 0.55 \\
\hline $\mathrm{Ca}$ & 0.05 & 0.03 & 0.03 & 0.03 \\
\hline
\end{tabular}

vial and digested in $\mathrm{HF}+\mathrm{HNO}_{3}+\mathrm{HCl}(7: 3: 1)$ in steel-lined pressure digestion vessel $\left(\mathrm{Parr}^{\circledR}\right.$, USA). The solutions were passed through $\mathrm{HCl}$ columns to separate $\mathrm{Rb}, \mathrm{Sr}$ and REE. The isotopic analysis was performed using thermal ionisation mass spectrometer (Triton, Thermo-Finnigan) at Department of Earth Sciences, Pondicherry University. Details of isotope analysis followed in this study are given in Anand and Balakrishnan (2010).

\section{Results}

\subsection{Petrography and mineral chemistry of granitic rocks}

\subsubsection{Sewariya granite}

SG contains K-feldspar, sodic plagioclase and quartz, along with accessory biotite and muscovite. Fine-to-coarse flakes of biotite and muscovite are generally aligned along a plane, which define the gneissic foliation of the SG, and often show kink bands. Adjacent to wolframite mineralised quartz veins, SG has undergone hydrothermal alteration which has resulted in the replacement of K-feldspar by muscovite and quartz (figure 3a) and replacement of biotite by tourmaline (figure $3 \mathrm{~b}$ ). Hydrothermal tourmaline from SG contains inclusions of quartz and shows irregularly 
distributed patches of blue and greenish yellow (figure $3 \mathrm{~b}$ ). These alterations indicate that the hydrothermal fluid was acidic and rich in boron. The hydrothermal tourmaline of SG is distinctly different from magmatic tourmaline of GG in having larger 'a' and 'c' cell dimensions (Sivasubramaniam 2005). The chemical analysis of this tourmaline shows the composition close to schorl (table 2).

SG from protomylonite is medium grained with few megacrysts (up to few centimetres) of microcline which appear to be porphyroblasts around which micas swerve, and shows the development of quartz ribbons. SG from ultramylonite contains about $90 \%$ of fine- to very-fine-grained matrix in which porphyroblastic grains of quartz, K-feldspar and micas (in the size range of $4-20 \mathrm{~mm}$ ) are disseminated. Thin quartz ribbons containing finegrained quartz are also observed in ultramylonite (figure 3c). Cataclastic bands in SG, as small as less than an $\mathrm{mm}$ wide, show intense brecciation and size reduction of constituent minerals and whose effect also extends into the adjoining coarse mineral grains of SG (figure 3d). Thin sections of

Table 4. Major and trace element composition of $S G$ and $G G$.

\begin{tabular}{|c|c|c|c|c|c|c|c|c|c|c|c|c|c|}
\hline Sample & SG-115 & SG-116 & SG-138 & SG-147 & SG-150 & SG-221 & SG-251 & & & & & & \\
\hline \multicolumn{14}{|c|}{ Sewariya granite } \\
\hline $\mathrm{SiO}_{2}$ & 72.49 & 71.05 & 72.25 & 71.33 & 70.42 & 68.55 & 74.56 & & & & & & \\
\hline $\mathrm{TiO}_{2}$ & 0.11 & 0.09 & 0.12 & 0.23 & 0.21 & 0.31 & 0.08 & & & & & & \\
\hline $\mathrm{Al}_{2} \mathrm{O}_{3}$ & 13.59 & 14.74 & 13.55 & 14.11 & 14.1 & 14.18 & 13.92 & & & & & & \\
\hline $\mathrm{Fe}_{2} \mathrm{O}_{3}$ & 1.91 & 1.62 & 1.85 & 2.35 & 2.34 & 3.01 & 1.63 & & & & & & \\
\hline $\mathrm{MnO}$ & 0.03 & 0.03 & 0.03 & 0.04 & 0.04 & 0.05 & 0.03 & & & & & & \\
\hline $\mathrm{MgO}$ & 0.24 & 0.26 & 0.25 & 0.51 & 0.76 & 0.66 & 0.19 & & & & & & \\
\hline $\mathrm{CaO}$ & 0.71 & 0.65 & 0.73 & 1.41 & 1.55 & 1.94 & 0.64 & & & & & & \\
\hline $\mathrm{Na}_{2} \mathrm{O}$ & 2.81 & 2.7 & 2.92 & 2.11 & 2.53 & 2.87 & 3 & & & & & & \\
\hline $\mathrm{K}_{2} \mathrm{O}$ & 5.01 & 5.49 & 4.92 & 5.06 & 3.99 & 4.56 & 5.43 & & & & & & \\
\hline $\mathrm{P}_{2} \mathrm{O}_{5}$ & 0.16 & 0.18 & 0.16 & 0.16 & 0.14 & 0.24 & 0.15 & & & & & & \\
\hline $\mathrm{Ba}$ & 22 & - & 14 & 456 & 159 & 670 & 20 & & & & & & \\
\hline $\mathrm{Rb}$ & 441 & 581 & 444 & 246 & 272 & 49 & 212 & & & & & & \\
\hline $\mathrm{Sr}$ & 27 & 30 & 25 & 72 & 46 & 139 & 100 & & & & & & \\
\hline $\mathrm{Y}$ & 28 & 28 & 28 & 37 & 29 & 4 & 37 & & & & & & \\
\hline $\mathrm{Zr}$ & 75 & 66 & 75 & 120 & 104 & 31 & 169 & & & & & & \\
\hline $\mathrm{Nb}$ & 10 & 12 & 12 & 9 & 11 & 2 & 14 & & & & & & \\
\hline $\mathrm{Li}$ & $<5$ & $<5$ & 25 & 36 & 40 & $<5$ & $<5$ & & & & & & \\
\hline W & & & & & 6 & 4 & & & & & & & \\
\hline Sample & G-101 & G-105 & G-127 & G-130A & G-134 & G-136A & G-141A & G-142 & G-144 & G-148 & G-235 & G-245 & G-264 \\
\hline \multicolumn{14}{|c|}{ Medium-grained Govindgarh granite } \\
\hline $\mathrm{SiO}_{2}$ & 74.09 & 71.57 & 70.7 & 72.27 & 72.97 & 73.43 & 73.36 & 70.29 & 71.63 & 74.87 & 71.75 & 71.21 & 72.79 \\
\hline $\mathrm{TiO}_{2}$ & 0.01 & - & 0.01 & 0.01 & 0.01 & - & 0.01 & - & 0.01 & - & - & 0.06 & 0.03 \\
\hline $\mathrm{Al}_{2} \mathrm{O}_{3}$ & 14.85 & 15.12 & 15.26 & 15.13 & 14.99 & 14.62 & 14.57 & 14.15 & 14.82 & 14.75 & 14.89 & 14.56 & 14.8 \\
\hline $\mathrm{Fe}_{2} \mathrm{O}_{3}$ & 0.7 & 0.55 & 0.45 & 0.35 & 0.44 & 0.64 & 0.24 & 0.39 & 0.86 & 0.68 & 0.72 & 0.81 & 0.75 \\
\hline $\mathrm{MnO}$ & 0.04 & 0.02 & 0.03 & 0.03 & 0.02 & 0.04 & 0.02 & 0.01 & 0.07 & 0.02 & 0.02 & 0.02 & 0.02 \\
\hline $\mathrm{MgO}$ & 0.16 & 0.12 & 0.12 & 0.18 & 0.16 & 0.09 & 0.14 & 0.1 & 0.15 & 0.1 & 0.13 & 0.18 & 0.28 \\
\hline $\mathrm{CaO}$ & 0.55 & 0.49 & 0.54 & 1.11 & 0.51 & 0.52 & 1.18 & 0.47 & 0.46 & 0.5 & 0.87 & 0.67 & 1.16 \\
\hline $\mathrm{Na}_{2} \mathrm{O}$ & 3.59 & 6.07 & 6.3 & 6.03 & 4.03 & 5.71 & 3.74 & 5.78 & 4.14 & 7.04 & 6.8 & 4.73 & 4.43 \\
\hline $\mathrm{K}_{2} \mathrm{O}$ & 5.29 & 2.71 & 2.51 & 1.95 & 4.97 & 3.53 & 4.58 & 2.99 & 5.85 & 1.39 & 2.73 & 4.37 & 4.42 \\
\hline $\mathrm{P}_{2} \mathrm{O}_{5}$ & 0.12 & 0.2 & 0.36 & 0.07 & 0.15 & 0.1 & 0.07 & 0.21 & 0.39 & 0.2 & 0.08 & 0.29 & 0.14 \\
\hline $\mathrm{Ba}$ & 206 & 17 & - & - & 125 & - & 57 & 11 & 172 & - & 20 & 153 & 20 \\
\hline $\mathrm{Rb}$ & 174 & 143 & 156 & 96 & 169 & 185 & 205 & 177 & 155 & 70 & 49 & 487 & 183 \\
\hline $\mathrm{Sr}$ & 85 & 36 & 22 & 45 & 69 & 20 & 63 & 54 & 65 & 29 & 109 & 18 & 90 \\
\hline $\mathrm{Y}$ & 5 & 5 & 2 & 7 & 7 & 7 & 15 & 3 & 0 & 5 & 7 & 31 & 17 \\
\hline $\mathrm{Zr}$ & 47 & 42 & 39 & 24 & 35 & 43 & 21 & 35 & 32 & 40 & 45 & 68 & 39 \\
\hline $\mathrm{Nb}$ & 5 & 5 & 6 & 4 & 4 & 3 & 3 & 4 & 2 & 5 & 3 & 12 & 2 \\
\hline $\mathrm{Li}$ & 6 & 19 & $<5$ & 6 & 10 & 15 & $<5$ & $<5$ & 6 & 19 & $<5$ & 40 & 6 \\
\hline W & 5 & 7 & & & & 6 & 2 & & & 3 & & & 1 \\
\hline
\end{tabular}


Table 4. (Continued.)

\begin{tabular}{|c|c|c|c|c|c|c|c|c|c|c|}
\hline Sample & G-124 & G-128A & G-130B & G-133 & G-145 & G-232 & G-237A & G-241B & G-253 & G-259 \\
\hline \multicolumn{11}{|c|}{ Coarse-grained GG } \\
\hline $\mathrm{SiO}_{2}$ & 71.6 & 73.2 & 71.41 & 72.11 & 73.42 & 71.71 & 73.44 & 73.95 & 74.66 & 72.31 \\
\hline $\mathrm{TiO}_{2}$ & - & 0.02 & - & 0.02 & 0.01 & 0.01 & 0.01 & 0.03 & - & - \\
\hline $\mathrm{Al}_{2} \mathrm{O}_{3}$ & 15.84 & 15.2 & 14.24 & 14.73 & 14.82 & 14.48 & 13.7 & 14.8 & 13.87 & 15.95 \\
\hline $\mathrm{Fe}_{2} \mathrm{O}_{3}$ & - & 0.14 & 0.34 & 0.9 & 0.36 & 0.39 & 1.04 & 0.87 & 0.4 & 0.05 \\
\hline $\mathrm{MnO}$ & 0.03 & 0.01 & 0.01 & 0.07 & 0.03 & 0.01 & 0.02 & 0.02 & 0.02 & - \\
\hline $\mathrm{MgO}$ & 0.1 & 0.19 & 0.14 & 0.18 & 0.15 & 0.18 & 0.17 & 0.33 & 0.11 & 0.13 \\
\hline $\mathrm{CaO}$ & 0.45 & 1.59 & 0.94 & 0.96 & 0.87 & 1.01 & 0.94 & 0.52 & 0.64 & 0.36 \\
\hline $\mathrm{Na}_{2} \mathrm{O}$ & 9.02 & 5.97 & 5.43 & 6.08 & 4.63 & 6.32 & 6.02 & 4.95 & 6.31 & 2.09 \\
\hline $\mathrm{K}_{2} \mathrm{O}$ & 1.14 & 1.68 & 2.36 & 1.59 & 3.95 & 1.93 & 1.62 & 3.15 & 2.21 & 10.37 \\
\hline $\mathrm{P}_{2} \mathrm{O}_{5}$ & 0.46 & 0.12 & 0.06 & 0.12 & 0.12 & 0.11 & 0.09 & 0.23 & 0.22 & 0.08 \\
\hline $\mathrm{Ba}$ & 6 & 27 & - & 20 & 183 & 83 & 20 & 20 & 20 & 422 \\
\hline $\mathrm{Rb}$ & 66 & 79 & 71 & 62 & 157 & 159 & 167 & 328 & 94 & 304 \\
\hline $\mathrm{Sr}$ & 35 & 44 & 88 & 72 & 118 & 48 & 40 & 197 & 33 & 168 \\
\hline $\mathrm{Y}$ & 35 & 44 & 88 & 72 & 118 & 48 & 40 & 197 & 33 & 168 \\
\hline $\mathrm{Zr}$ & 29 & 30 & 21 & 54 & 25 & 56 & 29 & 50 & 25 & 26 \\
\hline $\mathrm{Nb}$ & $<5$ & $<5$ & $<5$ & 9 & $<5$ & 5 & 8 & 8 & 7 & $<5$ \\
\hline $\mathrm{Li}$ & $<5$ & $<5$ & $<5$ & 9 & $<5$ & 5 & 8 & 8 & 7 & $<5$ \\
\hline W & 11 & & & & & & & 2 & & 3 \\
\hline
\end{tabular}

Table 5. REE abundances (in ppm) in granites and mica schist of Sewariya-Govindgarh area.

\begin{tabular}{|c|c|c|c|c|c|c|c|c|c|c|c|c|}
\hline \multirow[b]{2}{*}{ REE } & \multicolumn{4}{|c|}{ MGG } & \multicolumn{2}{|c|}{ CGG } & \multicolumn{3}{|c|}{ SG } & \multicolumn{3}{|c|}{ Barotiya mica schist } \\
\hline & G-101 & G-105 & G-141A & G-245 & G-241B & G-259 & SG-138 & SG-150 & SG-221 & G-210 & G-313 & G-119 \\
\hline $\mathrm{La}$ & 2.13 & 2.07 & 4.45 & 8.86 & 1.55 & 1.32 & 9.15 & 19.48 & 39.56 & 44.38 & 45.74 & 38.84 \\
\hline $\mathrm{Ce}$ & 4.3 & 4.21 & 7.99 & 15.11 & 3.16 & 2.43 & 20.79 & 41.6 & 83.85 & 83.55 & 91.21 & 78.95 \\
\hline $\mathrm{Nd}$ & 1.58 & 0.99 & 2.46 & 5.14 & 1.28 & 0.69 & 8.46 & 16.73 & 35.75 & 35.46 & 36.5 & 31.83 \\
\hline $\mathrm{Sm}$ & 0.36 & 0.32 & 0.6 & 0.98 & 0.25 & 0.27 & 2.03 & 3.15 & 5.94 & 5.35 & 5.45 & 4.87 \\
\hline $\mathrm{Eu}$ & 0.53 & 0.08 & 0.52 & 0.33 & 0.13 & 1.07 & 0.17 & 0.52 & 1.4 & 1.3 & 1.29 & 1.11 \\
\hline $\mathrm{Gd}$ & 0.35 & 0.26 & 0.92 & 1.3 & 0.21 & 0.18 & 3.6 & 4.87 & 8.21 & 6.87 & 6.68 & 6.3 \\
\hline Dy & 0.79 & 0.69 & 2.06 & 1.6 & 0.59 & 0.55 & 4.48 & 4.63 & 6.66 & 5.74 & 6.08 & 5.17 \\
\hline Er & 0.61 & 0.4 & 1.34 & 0.69 & 0.38 & 0.33 & 1.42 & 1.74 & 3.3 & 3.41 & 3.5 & 2.87 \\
\hline $\mathrm{Yb}$ & 0.87 & 0.5 & 1.89 & 0.82 & 0.41 & 0.43 & 0.81 & 1.24 & 2.82 & 3.44 & 3.55 & 2.85 \\
\hline$(\mathrm{Ce} / \mathrm{Yb})_{N}$ & 1.26 & 2.16 & 1.08 & 4.7 & 1.96 & 1.46 & 6.57 & 8.58 & 7.61 & 6.21 & 6.57 & 7.09 \\
\hline$(\mathrm{Dy} / \mathrm{Yb})_{N}$ & 0.58 & 0.89 & 0.7 & 1.25 & 0.92 & 0.83 & 3.54 & 2.39 & 1.51 & 1.07 & 1.1 & 1.16 \\
\hline $\mathrm{Eu} / \mathrm{Eu}^{*}$ & 4.5 & 0.83 & 2.16 & 0.92 & 1.71 & 14.14 & 0.19 & 0.41 & 0.62 & 0.66 & 0.66 & 0.62 \\
\hline$(\mathrm{Sm}+\mathrm{Gd})_{N} / 2$ & 1.63 & 1.34 & 3.35 & 5.06 & 1.07 & 1.05 & 12.24 & 17.6 & 31.32 & 27.19 & 27.09 & 24.84 \\
\hline
\end{tabular}

pseudotachylite show a mixture of glassy matrix and very-fine-grained to fine-grained clasts mostly comprising quartz, with sharp contact with the medium- to coarse-grained SG (figure 3e).

\subsubsection{Govindgarh granite}

Both medium- and coarse-grained GG contain Na-plagioclase, microcline and quartz as essential minerals, and accessory muscovite, tourmaline, garnet and apatite. XRD analysis shows that the plagioclase is albite, and the composition of tourmaline lies close to schorl in schorl-dravite series. Tourmaline shows dichorism in shades of blue, green, yellow and colourless with characteristic colour zoning in different intrusive phases: a small zone of blue core while rest of the grain is greenish yellow in early formed MGG (figure 3f); and a large zone of blue core surrounded by a narrow zone of yellowish green rim in CGG (figure $3 \mathrm{~g}$ ); yellow core and orange rim in the last formed hydrothermal tourmaline in wolframite mineralised quartz veins. The chemical composition of these tourmalines (table 2) generally corresponds with schorl (Fe-rich) variety except for few Mg-rich tourmalines from MGG and hydrothermal 
quartz veins having a composition in the range of schorl-dravite. Reddish-brown garnet (figures $2 \mathrm{~b}$ and $3 \mathrm{~h}$ ), and blue and green apatite are common accessories in MGG. The chemical composition of garnet (table 3 ) shows that it is dominantly of almandine composition with significant spessartite component $\left(\mathrm{Py}_{3.7} \mathrm{Alm}_{75.7} \mathrm{Gro}_{1.2} \mathrm{Sp}_{19.4}\right)$.

Similar to SG, GG occurring close to Wmineralised quartz veins has undergone hydrothermal alteration (Pandian and Dutta 2000).

\subsection{Geochemical characteristics of granites}

\subsubsection{Major and minor element geochemistry}

In Harker variation, diagrams of major and minor elements (in oxide wt\%) of SG and GG are given in figure 4. $\mathrm{SG}$ has a wide range of $\mathrm{SiO}_{2}(68.55-74.56$ wt\%), narrow range of alkalis (mean $\mathrm{K}_{2} \mathrm{O} 4.92 \mathrm{wt} \%$ and $\mathrm{Na}_{2} \mathrm{O} 2.71$ wt\%), A/CNK ratio 1.51-1.74 and normative corundum 1.53-3.57 wt\%. $\mathrm{K}_{2} \mathrm{O}$ in $\mathrm{SG}$ is higher than that of GG and shows a slight increase with increasing $\mathrm{SiO}_{2}$. CaO content of SG (0.64$1.94 \mathrm{wt} \%)$ decreases with increasing silica content. Similarly, $1.62-3.01 \mathrm{wt} \%$ of $\mathrm{Fe}_{2} \mathrm{O}_{3}$ and $\mathrm{MgO}$ contents of SG also decrease with increasing silica content which could be related to in-situ crystal fractionation of biotite. The relative proportion of mafic components $\mathrm{TiO}_{2}+\mathrm{Fe}_{2} \mathrm{O}_{3}+\mathrm{MgO}$ is generally higher in SG (ranges from 1.9 to $3.98 \mathrm{wt} \%$ with a mean of $2.67 \mathrm{wt} \%$ ). Higher total iron oxide and $\mathrm{TiO}_{2}$ wt\% in SG are due to the presence of biotite.

In contrast to SG, GG is characterised by narrow range of $\mathrm{SiO}_{2}$ (70.29-74.87 and 71.41-74.66 wt\% $\mathrm{SiO}_{2}$ in MGG and CGG, respectively) and a wide range of alkalis (mean $\mathrm{Na}_{2} \mathrm{O} 5.26,5.68 \mathrm{wt} \%$ and $\mathrm{K}_{2} \mathrm{O} 3.64,3.00 \mathrm{wt} \%$, respectively, in MGG and CGG). All samples of GG contain normative corundum (0.71-2.55 and 0.20-3.06 wt\% in MGG and CGG, respectively) with $\mathrm{A} / \mathrm{CNK}$ ratio of $1.41-1.66$ in MGG and 1.24-1.71 in CGG. $\mathrm{Na}_{2} \mathrm{O}$ and $\mathrm{Al}_{2} \mathrm{O}_{3}$ contents (14.15-15.26 wt\% in MGG and 13.70 15.95 wt\% in CGG) are higher and show a wide range in GG. The relative proportion of mafic components $\mathrm{TiO}_{2}+\mathrm{Fe}_{2} \mathrm{O}_{3}+\mathrm{MgO}$ is generally low in GG (0.39-1.06 wt\% in MGG and $0.1-1.23 \mathrm{wt} \%$ in CGG).

Quartz-alkali feldspar-plagioclase ternary modal classification (Streckeisen 1974, 1976; Winter 2001) is widely used to determine the nature of the main magma series (Lameyre and Bowden 1982; Lameyre and Bonin 1991). Ternary minima and ternary eutectic composition of the water saturated system at $P_{\mathrm{H}_{2} \mathrm{O}}=0.5,2,4,5 \mathrm{kbar}$ (figure 5) shows that SG falls close to the ternary minima (haplogranite field) in $\mathrm{Qz}-\mathrm{Or}-\mathrm{Ab}-\mathrm{H}_{2} \mathrm{O}$ diagram (Tuttle and Bowen 1958; Winkler 1979) corresponding to water pressures of 500-3000 bar. Some samples of GG lie close to ternary minima at relatively higher water pressures between 3000 and 5000 bar, while many samples of GG are scattered away from ternary minima for different water pressures. The displacement of some samples away from the minima is probably a result of melt segregation and therefore some of the samples do not represent the true bulk composition of the granitic melt. The relative positions of SG and GG in the same plot also indicate that the generation of SG melt took place at lower water pressures as compared to that of $\mathrm{GG}$ melt.

\subsubsection{Trace element geochemistry}

Bivariate plots of $\mathrm{Rb}, \mathrm{Nb}, \mathrm{Zr}$ and $\mathrm{Y}$ (figure 6) show a large difference between GG and SG in the concentration of these elements, with all these four elements enriched in SG as compared to GG. The range of concentration of $\mathrm{Rb}(212-581 \mathrm{ppm}), \mathrm{Sr}$ (18-100 ppm), Ba (14-670 ppm), Y (28-37 ppm), $\mathrm{Nb}(9-14 \mathrm{ppm})$ and $\mathrm{Zr}(66-69 \mathrm{ppm})$ is much wider in SG. In many bivariate plots of these trace elements, there is either positive correlation $(\mathrm{Nb}-\mathrm{Y}$, $\mathrm{Y}-\mathrm{Zr}, \mathrm{Sr}-\mathrm{Zr}, \mathrm{Sr}-\mathrm{Ba})$ or inverse relation (Rb-Sr) between pairs of trace elements. The composition of pseudotachylite (which occurs as irregular veins within SG) is comparable with SG in all elements, except for its relatively high $\mathrm{Y}$ and $\mathrm{Nb}$ content, and therefore it is inferred to have formed by nearcomplete flash melting of adjoining SG during the shearing event.

In the two varieties of $\mathrm{GG}$, the range of concentration of trace elements is relatively narrow and no correlation is discernible in the bivariate plots. The concentration of $\mathrm{W}$ in GG (1-7 ppm in MGG and 2-11 ppm in CGG) is higher compared to normal granites (1.5 ppm) and closely match with metallogenetically specialised granite reported by Tischendrof (1977). SG and mica schist have average $\mathrm{W}$ concentration of 5 and $8 \mathrm{ppm}$, respectively, which is attributed to fluid-rock interaction accompanying GG magmatism and related hydrothermal $\mathrm{W}$ mineralisation. In figure 7 , the concentration of $\mathrm{Zr}$ in $\mathrm{SG}$ and $\mathrm{GG}$ is compared with the proportion of $\mathrm{Zr}$ that can be dissolved in granite melts of various compositions at different temperatures (Watson and Harrison 1983). It 

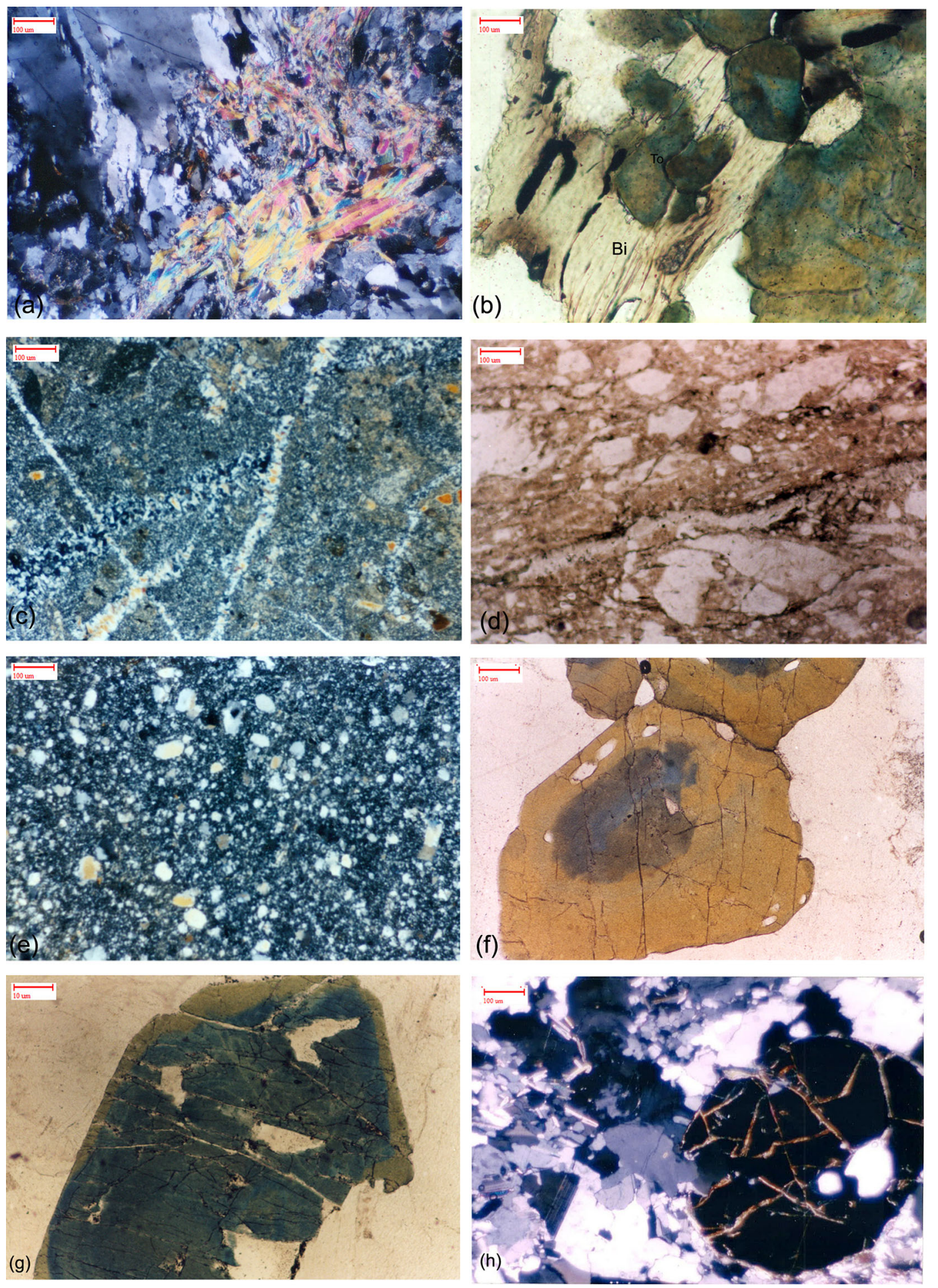

Figure 3. (a) Replacement of K-feldspar by muscovite and quartz in SG near W-mineralised quartz vein, XPL; (b) replacement of biotite in SG by tourmaline showing irregular colour zoning in patches of blue and greenish yellow, PPL; (c) ultramylonite in SG having thin quartz veins, XPL; (d) protomylonite in SG with few megacrysts of microcline, PPL; (e) pseudotachylite in SG showing a mixture of glassy matrix and very-fine-grained to fine-grained clasts mostly comprising quartz, XPL; (f) tourmaline in medium-grained GG shows colour zoning with a small zone of blue core and rest of the grain is greenish yellow, PPL; (g) tourmaline in coarse-grained GG shows colour zoning with a large zone of blue core and a thin greenish yellow rim, PPL; (h) garnet in medium-grained GG, XPL. 

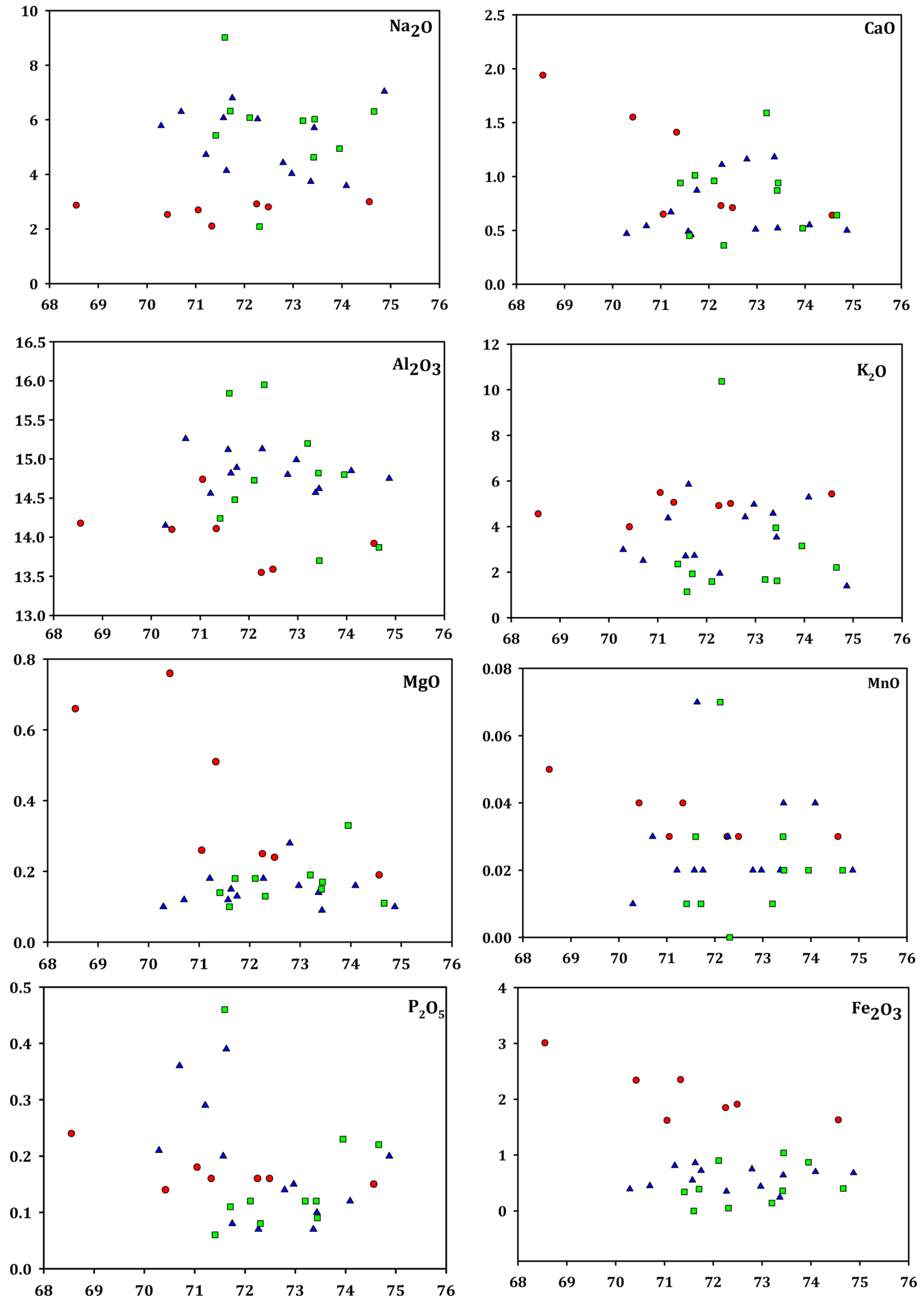

Figure 4. Harker variation diagrams of silica vs. other oxides (wt\%) in GG and SG (triangle - MGG; square - CGG; circle $-\mathrm{SG})$. 


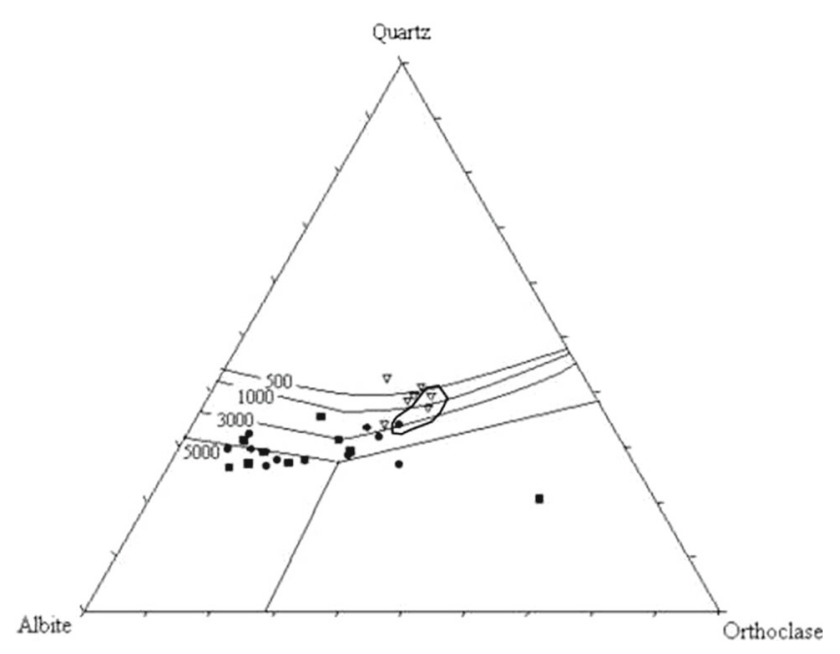

Figure 5. The plot of SG and GG in quartz-albiteorthoclase phase diagram (Winter 2001). Cotectic curves for water-saturated melt in equilibrium with quartz and alkali feldspar at different confining pressures (in bar) and the haplo granite field are marked (circle-MGG; square-CGG; inverted triangle - SG).

is observed that the samples of GG fall at lower temperatures $\left(<750^{\circ} \mathrm{C}\right)$ compared to those of $\mathrm{SG}$ $\left(>750^{\circ} \mathrm{C}\right)$. It also observed that there is a difference between early formed MGG (mostly above $700^{\circ} \mathrm{C}$ ) and late formed CGG (many below $700^{\circ} \mathrm{C}$ ) in this diagram. Low concentration of $\mathrm{Zr}$ in $\mathrm{GG}$ $(<70 \mathrm{ppm})$ suggests relatively low temperatures of formation (Watson and Harrison 1983; Kalsbeek et al. 2001).

\subsubsection{REE geochemistry}

REE concentration of $S G$ and $G G$ is given in table 3. REE abundance of SG shows depleted negative slope pattern from LREE to HREE with strong negative $\mathrm{Eu}$ anomaly $\left[\left(\mathrm{Eu} / \mathrm{Eu}^{*}\right)<1\right.$, ranges from 0.19 to 0.62$]$. The high $(\mathrm{Ce} / \mathrm{Yb})_{N}$ value of 6.57-8.58 together with HREE depleted $(\mathrm{Dy} / \mathrm{Yb})_{N}$ value ranging from 1.51 to 3.54 in $\mathrm{SG}$ indicates a high degree of differentiation. The $\Sigma R E E$ is 50.91187.49 ppm in SG with LREE 100 times and HREE 10 times greater than chondrite.

GG is enriched in LREE and HREE, and depleted in middle REE, showing bowl shape with very small negative or positive Eu anomalies $\left[\left(\mathrm{Eu} / \mathrm{Eu}^{*}\right)>1\right.$ and ranges from 0.83 to 14.14$]$ in normalised REE plot. $(\mathrm{Ce} / \mathrm{Yb})_{N}$ ranges from 1.08 to 4.70 in GG with HREE enrichment from Dy to $\mathrm{Yb}$ and $(\mathrm{Dy} / \mathrm{Yb})_{N}$ in the range $0.58-1.25$. The $\Sigma$ REE of GG is $7.26-34.84 \mathrm{ppm}$ with only $5-40$ times greater than chondrite values.

\subsubsection{Rb-Sr isotope system}

The whole rock samples of SG and GG do not define any isochron in $\mathrm{Rb}-\mathrm{Sr}$ isotope evolution diagram. These granites must have assimilated country rocks resulting in inhomogeneous ${ }^{87} \mathrm{Sr} /{ }^{86} \mathrm{Sr}$ initial ratios. Such heterogeneities are expected from granite magmas derived by partial melting of continental crustal sources having an uneven distribution of biotite and muscovite. Hence, the ${ }^{87} \mathrm{Rb} /{ }^{86} \mathrm{Sr}$ initial ratio was brought down and the error on the isochron age is also high. When we consider only mineral isochron of MGG (G-134) for pure grains of muscovite, garnet, plagioclase (table 4), an age of $860.5 \pm 7.4 \mathrm{Ma}$ is obtained with an initial ${ }^{87} \mathrm{Sr} /{ }^{86} \mathrm{Sr}$ ratio of $0.7533 \pm 0.0050$ $(\mathrm{MSWD}=3.0)$ (figure 8a). In hydrothermally altered MGG (G-127), mineral isochron for pure muscovite, plagioclase and garnet defines an age of $847 \pm 37 \mathrm{Ma}$ with an initial ${ }^{87} \mathrm{Sr} /{ }^{86} \mathrm{Sr}$ ratio of 0.716 (MSWD = 64) (figure 8b). The hydrothermally altered granite (sample G-127) has yielded $\mathrm{Rb}-\mathrm{Sr}$ mineral isochron age which is indistinguishable from the unaltered sample. However, the hydrothermal alteration has increased the scatter as reflected in the higher MSWD value and error on the age compared to the unaltered granite (sample G-134). Hence, the mineral isochron age for the sample G-134 represents the time of crystallisation and closure of muscovite, garnet and plagioclase for $\mathrm{Rb}-\mathrm{Sr}$ isotopic system in the GG (table 6).

\section{Discussion and conclusions}

SG pluton is a biotite granite which has undergone extensive ductile and brittle deformation at different crustal levels. Contrary to this, GG is generally undeformed and occurs as stocks and dykes. SG and both varieties of GG are peraluminous with $\mathrm{A} / \mathrm{CNK}$ ratio $>1$. However, GG has a wider range of $\mathrm{A} / \mathrm{CNK}$ ratio, which is attributed to the presence of more number of alumino-silicate minerals (muscovite, tourmaline and garnet in addition to feldspars) and variation in their relative proportion. Garnet of GG is dominantly almandine with significant spessartite component which is typical of peraluminous granites (Clark 1981). The relative proportion of mafic components $\mathrm{TiO}_{2}+\mathrm{Fe}_{2} \mathrm{O}_{3}+\mathrm{MgO}$ higher in SG is due to the presence of biotite as an essential phase. The presence of euhedral tourmaline in GG reflects its early crystallisation from the parent magma which has 

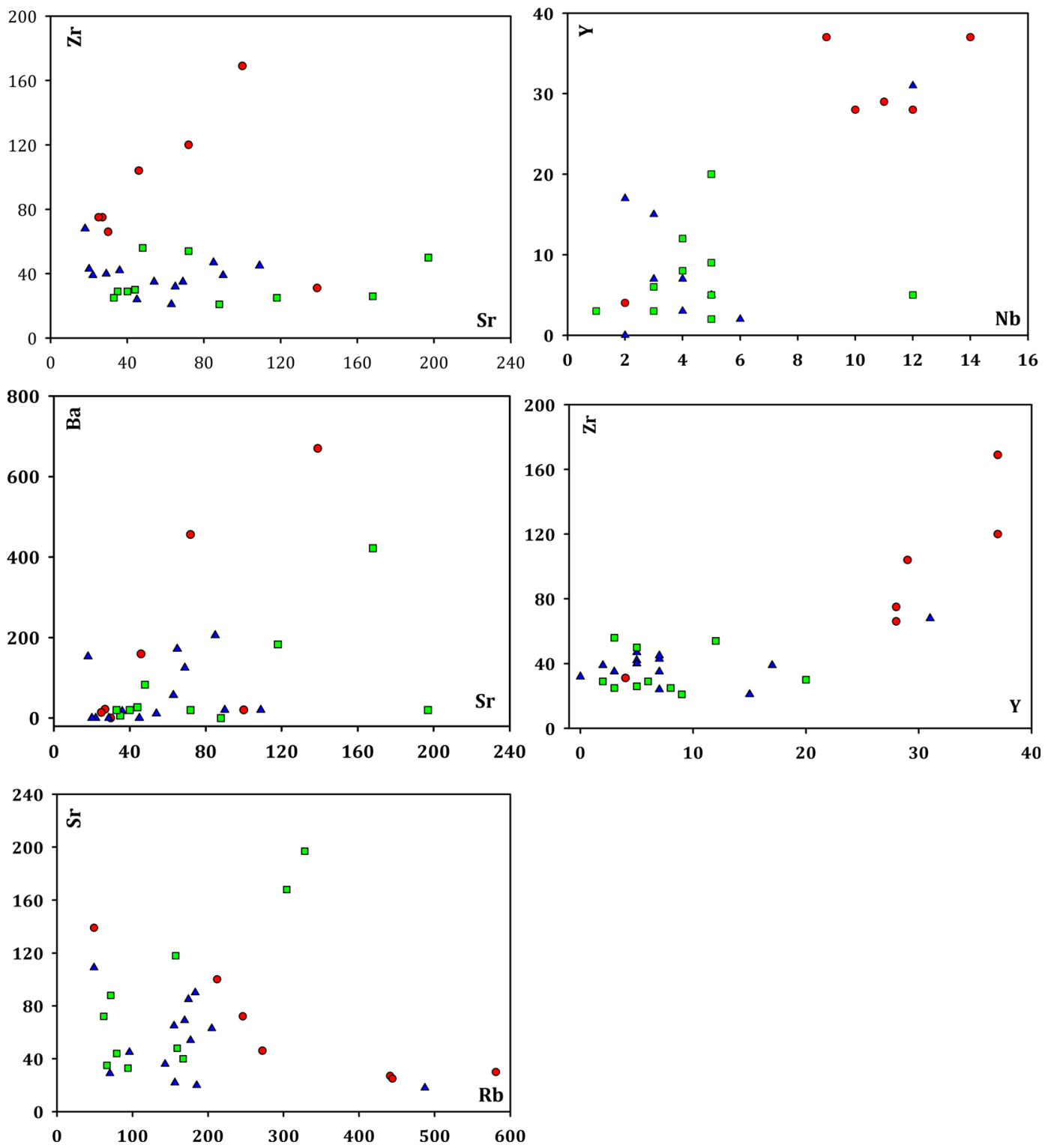

Figure 6. Trace element (in ppm) variation in GG and SG. Symbols are same as in figure 4.

minimised the formation of other ferromagnesian minerals and resulted in the absence of biotite. The relatively high $\mathrm{Na}_{2} \mathrm{O}$ and $\mathrm{Sr}$ concentrations and positive Eu anomaly in MGG and CGG are due to the higher modal per cent of sodic plagioclase in these leucogranites. The positive Eu anomalies in the chondrite-normalised plot are invariably associated with the relatively high concentration of $\mathrm{Sr}$ (and in some cases $\mathrm{Ba}$ ) and vice versa for the low concentration.

Chappell (2004) has observed that higher $\mathrm{Zr}$ and $\mathrm{Y}$ concentrations are characteristic features of high-temperature granites in which melting continued to higher temperatures before the magma could depart its source, and that high-temperature granites owe their origin to insufficient low- temperature melt components (quartz, orthoclase, albite and water) in the source region. Higher concentration of $\mathrm{Zr}$ and $\mathrm{Y}$ is present in $\mathrm{SG}$ as compared to GG; therefore it indicates that SG melt was generated at a relatively higher temperature from a source rock which consisted of insufficient quartz, orthoclase, albite and water.

The multi-element primitive mantle-normalised spider diagram (figure 9) illustrates that $\mathrm{SG}$ is enriched in $\mathrm{Rb}$, La and Ce and strongly depleted in terms of $\mathrm{Sr}, \mathrm{P}$ and $\mathrm{Ti}$. GG has a lower concentration of trace elements (e.g., Zr, Y, REE) that mainly reside in accessory minerals of the source rock, which indicates that a significant proportion of these elements remained in the restite during anatectic generation of the granitic 


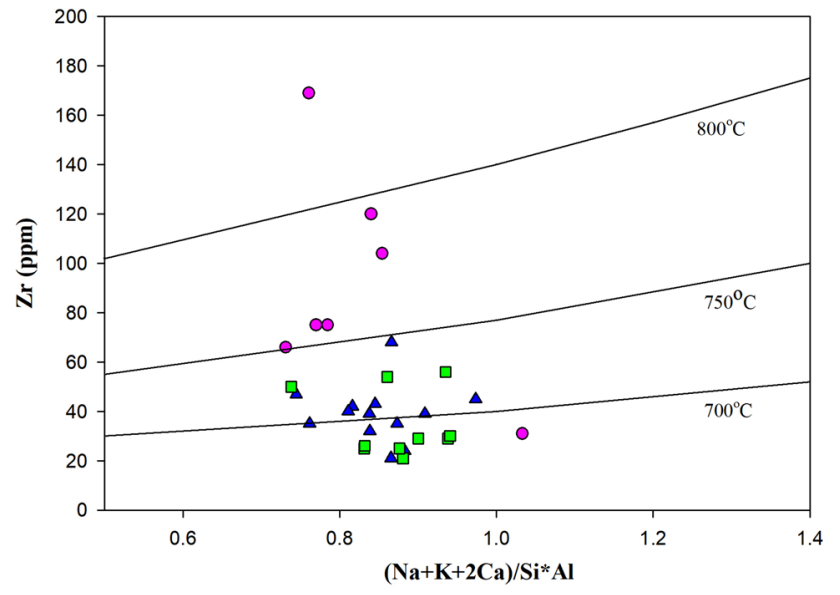

Figure 7. $\mathrm{Zr}$ concentration in the granites plotted against cation ratio $(\mathrm{Na}+\mathrm{K}+2 \mathrm{Ca}) /(\mathrm{Al} * \mathrm{Si})$ (after Watson and Harrison 1983). The temperature lines marked in the diagram are from Kalsbeek et al. (2001) (for $700^{\circ} \mathrm{C}$ ) and Watson and Harrison (1983) (for $750-800^{\circ} \mathrm{C}$ ) with extrapolations of the temperature line at the lower end from cation ratio 0.5 to 0.8. Symbols are same as in figure 4 .

magma (Rapp and Watson 1988, 1995; Kalsbeek et al. 2001). The patterns produced by GG and SG in this diagram are comparable with upper continental crust values (Taylor and McLennan 1981).

\subsection{Petrogenesis}

The high concentration of boron in GG revealed by the ubiquitous presence of tourmaline, together with high $\mathrm{A} / \mathrm{CNK}$ ratio of this rock shows that the source could be pelitic sediments (Skjerlie and Johnston 1996; Chappell and White 2001). In the study area, GG is closely associated with mica schist of Barotiya Group. Therefore, it is possible that the parent magma of GG could have been generated by partial melting of meta-sedimentary rocks of Barotiya Group. The REE pattern of GG is complementary to that of amphiboles, which are enriched in middle REE than LREE and HREE. The HREE abundances in the GG sample show that accessory phases such as garnet, zircon, apatite, allanite with amphibole could have played a major role in the generation of GG magma.

Geochemical modelling is carried out using the least mobile elements, such as the REEs. For quantitative modelling of partial melting and fractional crystallisation processes, appropriate $\mathrm{Kd}$ values for different source and melt systems, as suggested by Arth (1976), Hanson (1980), Nash and Crecraft (1985), have been used. In all, 5-30\% partial melting of a source similar to mica schist in the
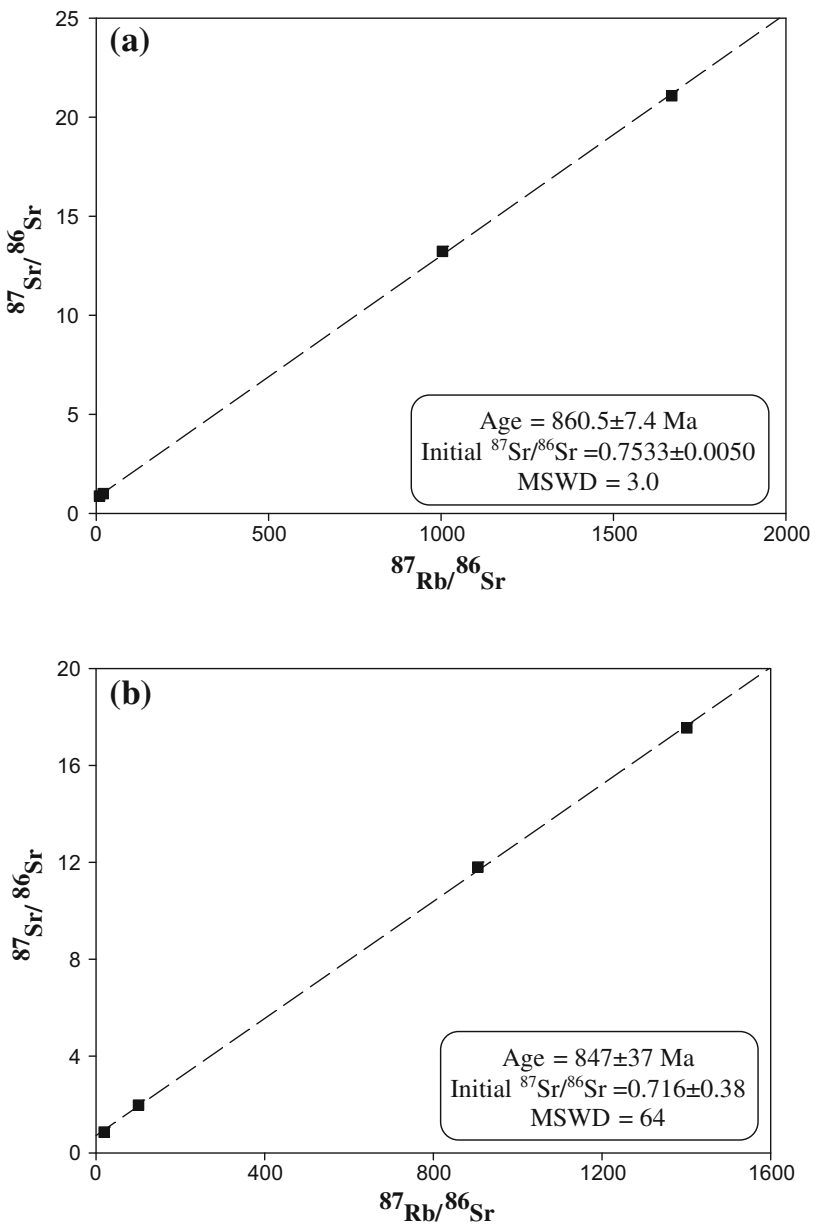

Figure 8. Rb-Sr mineral isochron for plagioclase+ garnet+muscovite in medium-grained GG: (a) unaltered sample, G-134 and (b) hydrothermally altered sample, G-127.

study area, leaving an amphibolite residue (90\% hornblende $+5 \%$ biotite $+5 \%$ apatite) would produce a melt having LREE enriched REE pattern with a positive $\mathrm{Eu}$ anomaly (figure 10). The calculated pattern shows that garnet and allanite fractionation played a major role in the generation of the GG magma. The calculated mica schist sample has higher REE abundance than GG samples. However, in a heterogeneous metasedimentary rock such as mica schist, it is expected that the range in REE abundance may be large enough to be comparable with the REE abundance of GG. The positive Eu anomaly in the GG could not be due to plagioclase accumulation as it would have also increased the Sr abundance which is not supported by the Sr abundances observed. Hence, it suggests that REE abundances and modelling for GG show that partial melting of a heterogeneous source leaving amphibolite residue would satisfy the REE abundances of GG. REE modelling of SG 
Table 6. Rb-Sr isotopic composition of $G G$.

\begin{tabular}{|c|c|c|c|c|c|}
\hline Sample name & Minerals & ${ }^{87} \mathrm{Rb} /{ }^{86} \mathrm{Sr}$ & Error $(\%)$ & ${ }^{87} \mathrm{Sr} /{ }^{86} \mathrm{Sr}$ & Error $(\%)$ \\
\hline \multirow[t]{4}{*}{ G-134 (medium-grained granite) } & Muscovite 1 & 1668.84 & 2 & 21.0806 & 0.1500 \\
\hline & Muscovite 2 & 1004.03 & 2 & 13.2260 & 0.1100 \\
\hline & Plagioclase & 9.76 & 2 & 0.875142 & 0.0208 \\
\hline & Garnet & 20.44 & 2 & 1.001800 & 0.0032 \\
\hline \multirow{4}{*}{$\begin{array}{l}\text { G-127 (medium-grained hydrothermally } \\
\text { altered granite) }\end{array}$} & Muscovite 1 & 1401.05 & 1 & 17.5500 & 0.1120 \\
\hline & Muscovite 2 & 905.62 & 1 & 11.8000 & 0.0856 \\
\hline & Plagioclase & 100.86 & 1 & 1.975600 & 0.0569 \\
\hline & Garnet & 19.48 & 1 & 0.862400 & 0.0900 \\
\hline
\end{tabular}
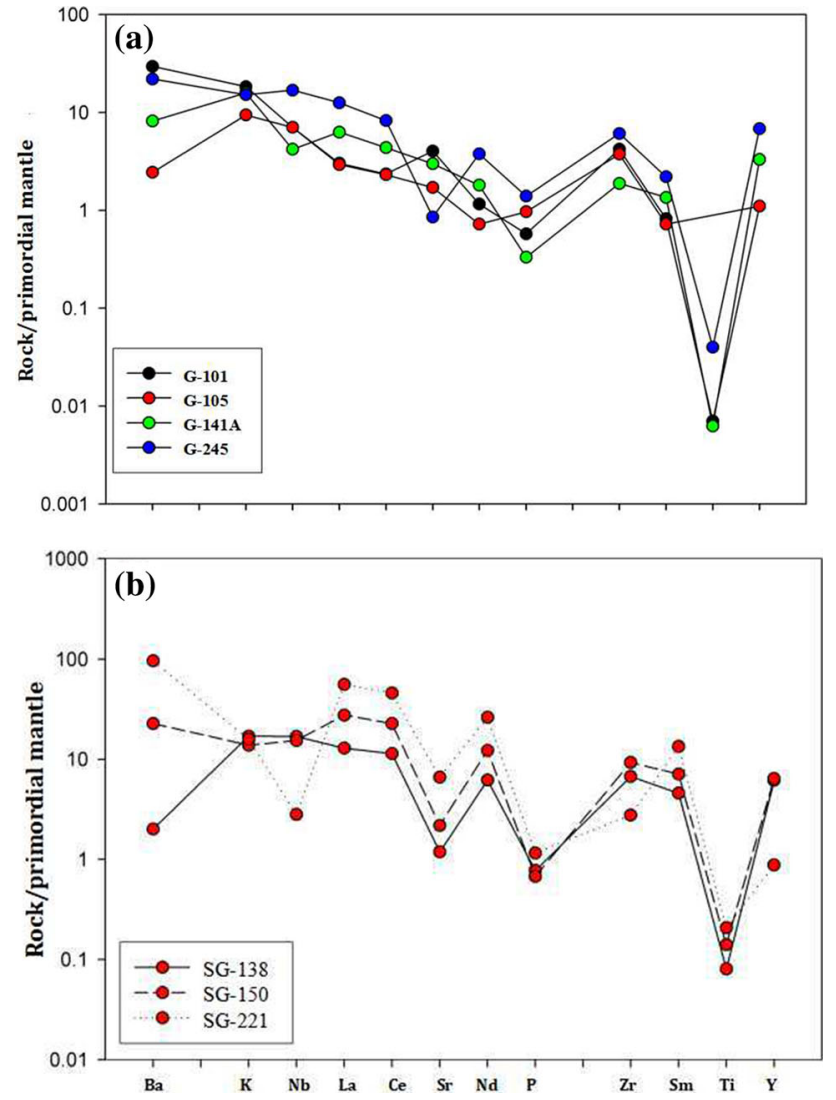

Figure 9. Primitive mantle-normalised spider diagram showing the granites from the study area (after Taylor and McLennan 1981): (a) medium-grained GG and (b) SG.

shows that 5-30\% partial melting of mica schist source leaving a granulite residue $(58 \%$ plag $+30 \%$ $\mathrm{Cpx}+10 \% \mathrm{Ox}+2 \%$ garnet) could have produced the parental granitic magma (figure 11). Subsequently, $5-30 \%$ fractional crystallisation of $50 \%$ plag $+49.5 \% \mathrm{Hb}+0.4 \%$ zircon $+0.1 \%$ allanite from this parental magma could have produced the magma from which SG was formed (figure 12).

The $\mathrm{Rb}-\mathrm{Sr}$ isochron age of $860.5 \pm 7.4 \mathrm{Ma}$ based on muscovite, garnet and plagioclase for the GG samples (G-134) represents the time of cooling of the granite body to $<400^{\circ} \mathrm{C}$. Several studies have

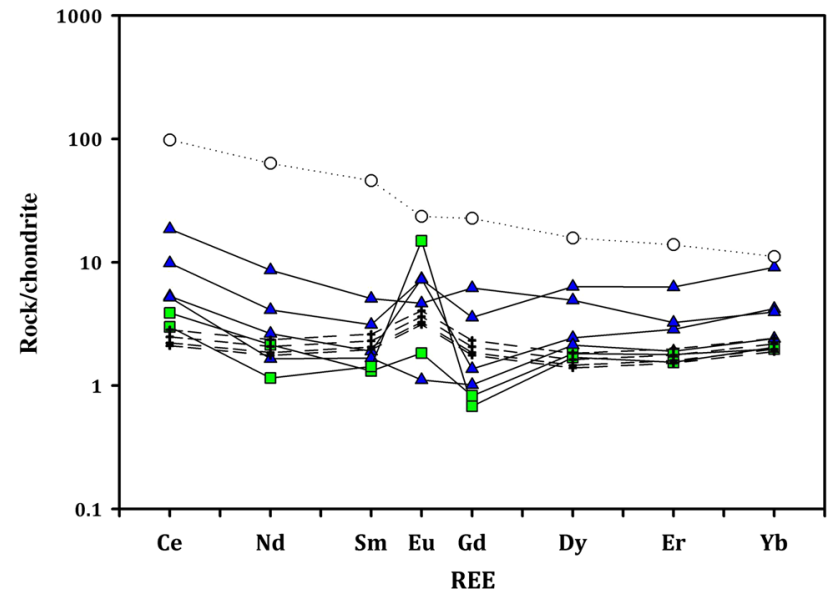

Figure 10. Calculated chondrite-normalised REE patterns for 5, 10, 15 and $20 \%$ partial melting of mica schist leaving residue $10 \% \mathrm{~K}$-feldspar $+15 \%$ plagioclase $+48 \%$ hornblende $+20 \%$ biotite $+5 \%$ apatite $+2 \%$ allanite. Calculated patterns (dashed lines) are analogous with GG samples except for very small negative $\mathrm{Eu}$ anomaly in one sample (G245). Symbols: a filled triangle with solid lines - MGG; a filled square with solid lines - CGG; plus with dotted lines - calculated melt; open circle - parent rock.

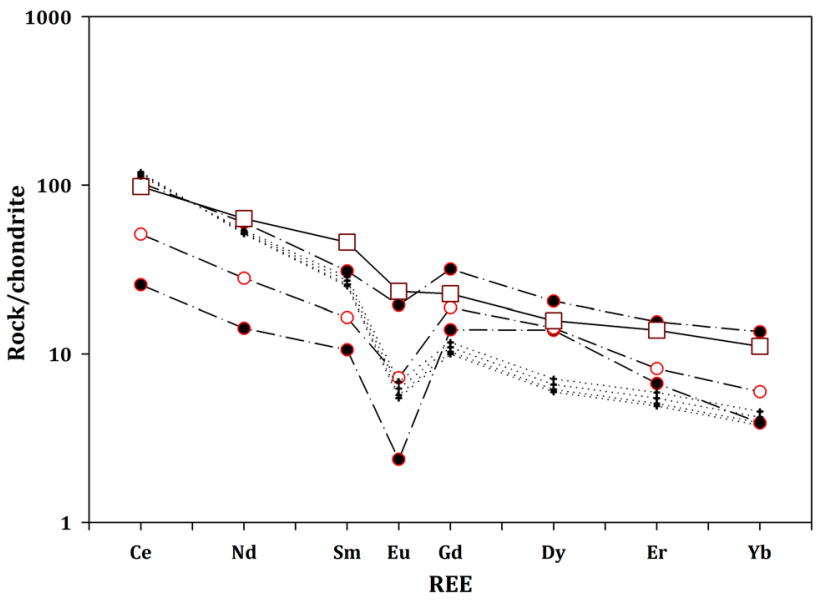

Figure 11. Calculated chondrite-normalised REE patterns for 5, 10, 20 and 30\% partial melting of mica schist source leaving residue of $58 \%$ plagioclase $+30 \%$ CPX $+10 \%$ OPX $+2 \%$ garnet. Symbols: circle $-\mathrm{SG}$; square - parent rock; plus - calculated melt. 


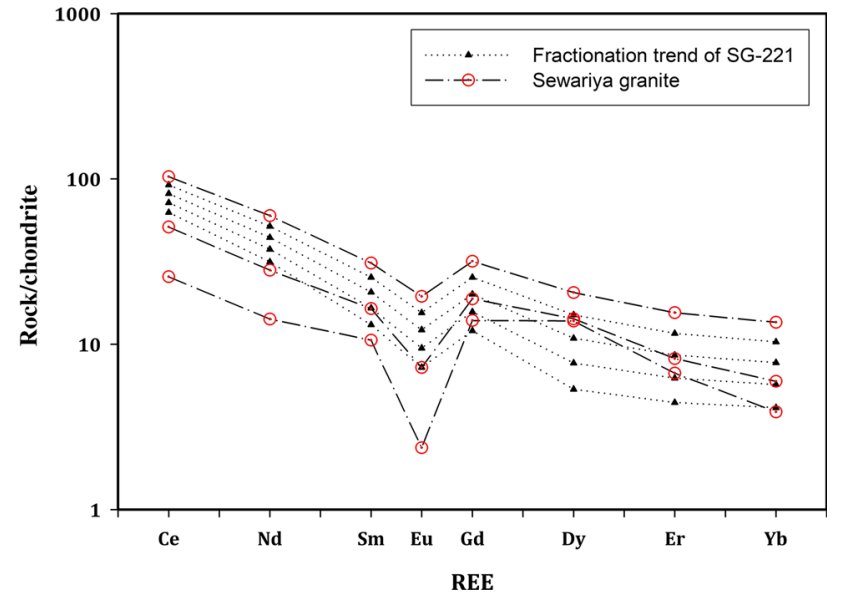

Figure 12. Calculated chondrite-normalised REE patterns for $5,10,20$ and $30 \%$ fractional crystallisation of $50 \%$ plagioclase $+49.5 \%$ biotite $+0.4 \%$ zircon $+0.1 \%$ allanite from parent SG-221. Calculated REE patterns are comparable with SG samples.

shown that igneous rocks that were not subjected to metamorphism or thermal disturbance exceeding a temperature of $400^{\circ} \mathrm{C}$ give $\mathrm{Rb}-\mathrm{Sr}$ muscovite ages that match with $\mathrm{U}-\mathrm{Pb}$ zircon ages within analytical uncertainties (Nebel et al. 2011). Thus, $\mathrm{Rb}-\mathrm{Sr}$ muscovite-garnet-plagioclase isochron ages represent the time of cooling of these igneous bodies to $<400^{\circ} \mathrm{C}$. Since GG was emplaced as relatively small stocks and dyke swarms, it must have cooled to $<400^{\circ} \mathrm{C}$ within a million year from the time of their intrusion. Hence, we consider that the $\mathrm{Rb}-$ $\mathrm{Sr}$ isochron age reported above is robust and date the time of igneous intrusion of the GG. Other two well-known granites associated with tungsten mineralisation along the western margin of the Delhi Fold Belt, at Balda and Deganna have yielded $\mathrm{Rb}-\mathrm{Sr}$ mineral isochron ages of $795 \pm 11$ and $827 \pm$ $8 \mathrm{Ma}$, respectively (Vijay Anand et al. 2018).

\subsection{Tungsten metallogeny in Delhi Fold Belt}

In the Aravalli craton, tungsten mineralisation is mainly associated with Neoproterozoic granites occurring along the western margin of Delhi fold belt. The following observations are made by comparing the tungsten mineralisation in GovindgarhSewariya area with the other well-known tungsten deposits at Degana and Balda. There are few similarities among these three tungsten deposits: (i) Mid-Proterozoic metasediments (dominated by pelites) are intruded by an older biotite granite which has been deformed along with metasediments, and a younger geochemically specialised granite which is the source for $\mathrm{W}$ mineralisation and (ii) ore mineralisation occurs in greisen-bordered quartz veins containing wolframite of ferberitic composition as the principal ore mineral. However, there are several dissimilarities among these tungsten deposits.

1. Mineral assemblage of source granite: Degana granite is F-Li-rich, contains topaz and zinnwaldite, and it is devoid of tourmaline (Pandian and Varma 2001). Balda granite is a muscovite-tourmaline-bearing leucogranite (Chattopadhyay et al. 1982).

2. Nature of acid magmatism related to $W$ mineralisation: Degana granite is a complex of three porphyritic granitic intrusions, two generations of aplite dykes, greisen-bordered quartz veins, rare pegmatite and a multitude of greisen veinlets, all occurring within a small area (Pandian and Varma 2001). Relative proportion aplite dykes are significantly large in Degana pluton. Balda granite is a single, continuous and homogeneous textured pluton exposed over a length of about $20 \mathrm{~km}$ and having a maximum width of about $1 \mathrm{~km}$. Quartz-rich veins and few pegmatites are present, whereas aplite dykes are not known in Balda area. In Sewariya area, GG is also a non-porphyritic granite, but occurs mostly as dyke swarm and few stocks emplaced within mica schist and older granite, and exposed over a zone $20 \mathrm{~km}$ long and few $\mathrm{km}$ wide. In the outcrop area, pegmatite component of GG (CGG) is more compared to MGG. Aplite dykes are not present in SewariyaGovindgarh area.

3. Nature of $W$ mineralisation: In Degana area, $\mathrm{W}$ mineralisation is essentially intrusion centred and marginally extends into adjoining phyllite. Two episodes of mineralisation are recognised, each preceded by emplacement of a porphyritic granite and aplite dykes (Pandian and Varma 2001). During each episode of $\mathrm{W}$ mineralisation, thick quartz lodes (up to $1 \mathrm{~m}$ ) and a multitude of thin greisen veinlets have formed. Due to the preponderance of greisen veinlets in addition to quartz lodes within granite pluton and adjoining phyllite, the host rocks of orebody show stockwork character. Ore veins often show crustification, with zinnwaldite/muscovite lining the wall and quartz in the core; wolframite and fluorite are disseminated within quartz. The mica associated with the first episode of mineralisation is zinnwaldite, and the one associated with the second event of mineralisation is 
muscovite. During the first episode of mineralisation, phyllite (of Phyllite Hill) is extensively brecciated, due to boiling of hydrothermal fluid. Such hydrothermal breccia is not known from the other two tungsten deposits.

In Balda area, wolframite-bearing quartz veins (few 10s of centimetre thick) are localised along the sheared intrusive contact of leucogranite against mica schist. Quartz makes up most of the veins, with tourmaline, beryl, fluorite, muscovite and wolframite (in decreasing order of abundance) disseminated within quartz. There are few fluorite-rich veins (containing relatively less proportion of quartz) occurring within the leucogranite. In Sewariya-Govindgarh areas, quartz-tourmaline veins containing wolframite occur exclusively along shear zones in mica schist and the older SG.

\section{Acknowledgements}

This work was supported by Scheme No. ESS/23/ VES/034/98 of DST, New Delhi to MSP. Rb-Sr isotope analysis was carried out using the National Facility for Geochronology and Isotope Geosciences at Pondicherry University funded by DST-IRPHA. The authors are thankful to the reviewers and editor for the constructive comments and suggestions to improve the paper.

\section{References}

Anand R and Balakrishnan S 2010 Pb, Sr and Nd isotope systematics of metavolcanic rocks of the Hutti greenstone belt, Eastern Dharwar craton: Constraints on age, duration of volcanism and evolution of mantle sources during Late Archean; J. Asian Earth Sci. 39 1-11.

Arif M, Nitnaware N V, Mahapatro S N, Baswani S R, Powar R R, Sridhar M and Dora M L 2017 Tungsten mineralisation in Lawari-Amboli area, Chandrapur district, Maharashtra, Western Bastar Craton; J. Geosci. Res. 1 73-80.

Arth J G 1976 Behaviour of trace elements during magmatic processes - A summary of theoretical models and their applications; J. Res. US Geol. Surv. 4 41-47.

Ashwal L, Solanki A, Pandit M, Corfu F, Hendriks B, Burke K and Torsvik T 2013 Geochronology and geochemistry of Neoproterozoic Mt. Abu granitoids, NW India: Regional correlation and implications for Rodinia paleogeography; Precamb. Res. 236 265-281.

Banerji S and Pandit M K 1995 Lithium and tungsten mineralisation in Sewariya pluton, South Delhi Fold Belt, Rajasthan: Evidences for preferential host rock affinity; Curr. Sci. 69 252-256.

Bhattacharjee J, Fareeduddin and Jain S S 1993 Tectonic setting, petrochemistry and tungsten metallogeny of the
Sewariya granite in the South Delhi Fold Belt, Rajasthan; J. Geol. Soc. India 42 3-16.

Chappell B W 2004 Towards a unified model of granite petrogenesis; In: Granites and associated metallogenesis The Ishihara Symposium (eds) Phil Blevin, Mel Jones and Bruce Chappell; Geosci. Australia, pp. 37-38.

Chappell B W and White A J R 2001 Two contrasting granite types: 25 years later; Aust. J. Earth Sci. 48 489-499.

Chattopadhyay B, Mukhopadhyay K, Singhai R K, Bhattacharjee J and Hore M K 1982 Post-Erinpura acid magmatism in Sirohi Rajasthan and its bearing on tungsten mineralisation; Proceedings of the symposium on metallogeny of the Precambrian IGCP, Project 91, pp. 115-132.

Chattopadhyay A K, Gill P S and Banerji S 1995 Exploration for tungsten and lithium mineralisation associated with Sewariya granite pluton, Ajmer, Pali and Nagaur Districts, Rajasthan; Rec. Geol. Surv. India 127 $43-45$.

Choudhary A, Gopalan K and Sastry C A 1984 Present status of the geochronology of the Precambrian rocks of Rajasthan; Tectonophys. 105 131-140.

Clark D B 1981 The mineralogy of peraluminous granites: A review; Can. Mineral. 19 3-17.

Crawford A R and Compston W 1970 The age of the Vindhyan system of peninsular India; J. Geol. Soc. Lond. 125 351-377.

Geological Survey of India 1982 Exploration of tungsten deposits; Indian Miner. 36 8-12.

Hanson G N 1980 Rare earth elements in petrogenetic studies of igneous systems; Ann. Rev. Earth Planet Sci. 8 371406.

Jain S S and Bhattacharjee J 1992 A note on the wolframite associated with the Sewariya granite pluton, Rajasthan; Indian Miner. 46 159-164.

Kalsbeek F, Hans F J and Allen P N 2001 From source migmatites to plutons: Tracking the origin of ca. $435 \mathrm{Ma}$ S-type granites in the East Greenland Caledonian orogen; Lithos $\mathbf{5} 7$ 1-21.

Lameyre J and Bonin B 1991 Granites in the main plutonic series; In: Enclaves and Granite Petrology (eds) Didier J and Barbarin B, Dev. Petrol. 13 3-17.

Lameyre J and Bowden P 1982 Plutonic rock type series: Discrimination of various granitoid rocks series and related rocks; J. Volcanol. Geotherm. Res. 14169 186.

Nash W P and Crecraft H R 1985 Partition coefficients for trace elements in silicic magmas; Geochim. Coscochim. Acta 49 2309-2322.

Nebel O, Scherer E E and Mezger K 2011 Evaluation of the ${ }^{87} \mathrm{Rb}$ decay constant by age comparison against the $\mathrm{U}-\mathrm{Pb}$ system; Earth Planet. Sci. Lett. 301 1-8.

Pandian M S 1999 Late Proterozoic acid magmatism and associated tungsten mineralisation in northwest India; Gondwana Res. 2 79-87.

Pandian M S and Dutta S K 2000 Leucogranite magmatism in Sewariya-Govindgarh areas of Rajasthan and its relevance to tungsten mineralisation; J. Geol. Soc. India 55 289-295.

Pandian M S and Varma O P 2001 Geology and geochemistry of topaz granite and associated wolframite 
deposit at Degana, Rajasthan; J. Geol. Soc. India 57 297-307.

Pandit M K, Carter L M, Ashwal L D, Tucker R D, Torsvik T H, Jamtveit B and Bhushan S K 2003 Age, petrogenesis and significance of $1 \mathrm{Ga}$ granitoids and related rocks from the Sendra area, Aravalli Craton, NW India; J. Asian Earth Sci. 22 363-381.

Rapp R P and Watson E B 1988 Partial melting of amphibolite/eclogite and the origin of tonalitic-trondhjemitic magmas; EOS 69521.

Rapp R P and Watson E B 1995 Dehydration melting of metabasalt at 8-32 kbar: Implications for continental growth and crust-mantle recycling; J. Petrol. 36 892-931.

Ray S, Kumar B J, Sundarraman S, Joshi D and Ahmad T 2015 Geochemical and petrogenetic study of Proterozoic Sewariya and Govindgarh granitoids from south Delhi fold belt; Curr. Sci. 109(8) 1458-1465.

Sivasubramaniam R 2005 Geology and geochemistry of granites and associated tungsten mineralisation in Govindgarh-Sewariya area along western margin of South Delhi Fold Belt, Rajasthan, India; PhD thesis, Pondicherry University, 176p.

Skjerlie K P and Johnston A D 1996 Vapour absent melting from 10 to $20 \mathrm{kbar}$ of crustal rocks that contain multiple hydrous phases: Implications for anatexis in deep continental crust and active continental margins; J. Petrol. 37 661-691.

Srivastava P K and Sinha A 1997 Geochemical characterization of tungsten-bearing granites from Rajasthan, India; J. Geochem. Exp. 60(2) 173-184.

Streckeisen A 1974 Classification and nomenclature of plutonic rocks recommendations of the IUGS subcommission on the systematics of Igneous Rocks; Int. J. Earth Sci. $\mathbf{6 3}$ $773-786$.

Streckeisen A 1976 To each plutonic rock its proper name; Earth Sci. Rev. 12 1-33.
Taylor S R and McLennan S M 1981 The composition and evolution of continental crust: Rare earth element evidence from sedimentary rocks; Phil. Trans. Roy. Soc. London 301A 381-399.

Tischendrof G 1977 Geochemical and petrographic characteristic of silicic magmatic rocks associated with rareelement mineralisation; In: Metallization Associated with Acid Magmatism (eds) Stemprok M, Burnol L and Tischendrof G, Geol. Surv. Czech. Prague 2 41-96.

Tobisch O T, Collerson K D, Bhattacharya $\mathrm{T}$ and Mukhopadhyay D 1994 Structural relationship and Sm$\mathrm{Nd}$ isotope systematic of polymetamorphic granitic gneisses and granitic rocks from central Rajasthan, India: Implications for evolution of the Aravalli craton; Precamb. Res. 65 319-339.

Torsvik T H, Carter L M, Ashwal L D, Bhushan S K, Pandit M K and Jamtveit B 2001 Rodinia refined or obscured: Palaeomagnetism of the Malani Igneous Suite (NW India); Precamb. Res. 108 319-333.

Tuttle O F and Bowen N L 1958 Origin of granites in the light of experimental studies in the system $\mathrm{NaAlSi}_{3} \mathrm{O}_{8}-$ $\mathrm{KAlSi}_{3} \mathrm{O}_{8}-\mathrm{SiO}_{2}-\mathrm{H}_{2} \mathrm{O}$; Geol. Soc. Am. Memoir 74153.

Vijay Anand S, Pandian M S, Balakrishnan S and Sivasubramaniam R 2018 Fluid inclusion, geochemical, Rb-Sr and $\mathrm{Sm}-\mathrm{Nd}$ isotope studies on tungsten mineralized Degana and Balda granites of the Aravalli craton, NW India; J. Earth Syst. Sci. 127(52) 1-200.

Watson E B and Harrison T M 1983 Zircon saturation revisited: Temperature and composition effects in a variety of crustal magma types; Earth Plantet. Sci. Lett. 64 295304.

Winkler H G F 1979 Petrogenesis of Metamorphic Rocks; Springer, Berlin, Heidelberg, New York, 348p.

Winter J D 2001 An Introduction to Igneous and Metamorphic Petrology; Prentice Hall, Upper Saddle River, NJ, $697 \mathrm{p}$. 